Article

\title{
Improvement of the Quality of Ginkgo biloba Leaves Fermented by Eurotium cristatum as High Value-Added Feed
}

\author{
Minmin Zou ${ }^{1}$, Xiaohan Guo ${ }^{1}$, Yan Huang ${ }^{1}$, Fuliang Cao ${ }^{2} \mathbb{D}$, Erzheng Su ${ }^{1,2,3}$ and \\ Jiahong Wang $1,2, * \mathbb{D}$ \\ 1 Department of Food Science and Technology, College of Light Industry and Food Engineering, \\ Nanjing Forestry University, Nanjing 210037, China; zouminmin@njfu.edu.cn (M.Z.); \\ XiaohanGuo_nj17@163.com (X.G.); yanhuang1991@126.com (Y.H.); sez17@163.com (E.S.) \\ 2 Co-innovation Center for the Sustainable Forestry in Southern China, College of Forestry, \\ Nanjing Forestry University, Nanjing 210037, China; fuliangcaonjfu@163.com \\ 3 State Key Laboratory of Natural Medicines, China Pharmaceutical University, Nanjing 210009, China \\ * Correspondence: njfuwjh@njfu.edu.cn; Tel.: +86-025-85428105
}

Received: 24 July 2019; Accepted: 9 September 2019; Published: 17 September 2019

\begin{abstract}
Ginkgo biloba leaves are well known for their high content of nutrients and bioactive substances. However, unpleasant smell and a small number of ginkgolic acids greatly reduce the utilization of the leaves. In this work, solid-state fermentation of G. biloba leaves using Eurotium cristatum was studied by investigation of the nutrient changes and its feasibility as a functional feed. E. cristatum could grow on pure G. biloba leaves and the addition of excipients could significantly improve the growth of E. cristatum. The optimal medium was with $10 \%(w / w)$ of whole G. biloba seeds and the optimized water content, $\mathrm{pH}$, inoculum size and fermentation time were $45 \%(w / w), 4.5$, $4.76 \times 10^{7} \mathrm{CFU} / 100 \mathrm{~g}$ wet medium, and eight days, respectively. Under the optimal conditions, the spore number increased by about 40 times. The content of flavonoids was greatly increased by $118.6 \%$, and the protein and polyprenyl acetates (PPAs) were increased by $64.9 \%$ and $10.6 \%$, respectively. The ginkgolic acids, lignin, and cellulose were decreased by $52.4 \%, 38.5 \%$, and $20.1 \%$ than before, respectively. Furthermore, the fermented G. biloba leaves showed higher antioxidant activity and held more aroma substances. Thus, G. biloba leaves fermented by E. cristatum have potential as s high value-added feed. This is the first investigation of E. cristatum fermentation on ginkgo leaves, which will facilitate the use of ginkgo leaves in the feed industry.
\end{abstract}

Keywords: ginkgo leaves; solid-state fermentation; E. cristatum strain; nutrients; active constituents

\section{Introduction}

The use of antibiotics in the feed industry once had positive effects on prevention of animal diseases and improvement of feed reward. However, concern has been raised regarding residue problems, which pose health threats to animals and humans [1]. For that reason, many countries have prohibited the utilization of antibiotics [2,3]. Therefore, effective substitutes are required. Fermented feed has attracted wide attention because of its low-cost, high nutritional value, and multifunctionality. Through microbial action, antinutrient factors, and macromolecular substances, raw materials can be decomposed or transformed into bioactive components such as organic acids, active small peptides, and growth factors [4]. The strains permitted for use in fermented feed include Bacillus subtilis, Saccharomyces, and Aspergillus, among others [3,5]. Bacillus subtilis can improve the growth performance of animals by secreting amylase, protease, and lipase [6]. Saccharomyces has the prominent ability of protein digestion and acid production to prevent antimicrobial-associated diarrhea [7,8]. However, 
both of them lack cellulase production, meaning that degradation of lignin and cellulose is difficult. As a mycelial fungus, Aspergillus can secret large amounts of protease and cellulase to improve the nutritive value of various substrates, which is especially suitable for solid-state fermentation of cellulose material $[9,10]$. E. cristatum, the dominant fungi species in Fuzhuan Brick Tea, is the teleomorph of Aspergillus [11]. Scholars have found that E. cristatum and its fermentation metabolites have many functions, including regulation of intestinal flora, bacteriostasis, antioxidation, and antineoplasticity, etc. $[12,13]$. Thus, E. cristatum has great potential when applied in the feed industry.

G. biloba L. is the sole living species of the once large plant division Ginkgophyta, which is commonly called an "archaic living fossil" [14,15]. Leaves of G. biloba L. are famous for their high content of flavonoids [16]. In addition, G. biloba leaves also contain many other components, including terpene trilactones (TTLs), procyanidine (PAC), and PPAs, as well as ginkgolic acids, which are considered to be allergenic compounds [14,17]. Numerous studies have shown that G. biloba leaves extract can be used to treat cognitive disorders, ischemic heart disease, arrhythmias, cancer, and diabetes [15]. Since the 1960s, G. biloba L. has been widely cultivated in China and the annual production of G. biloba leaves is about 40,000 tons [16]. The planting areas are mainly distributed in Sichuan, Jiangsu, Shandong, and Zhejiang provinces [5]. At present, the output of G. biloba leaves substantially exceeds the demand because the development and utilization of $G$. biloba leaves is currently unfavored. It is urgent to develop a way to take full advantage of this resource. Cao et al. have reported that $G$. biloba leaves can serve as a biological feed additive to promote the growth and immunity of yellow feather broilers [18]. Yang et al. have reported that G. biloba leaves of different proportions have different impacts on the growth performance of broilers [19]. Therefore, it is feasible that G. biloba leaves can be applied in the feed industry.

In this work, the fungal solid-state fermentation of G. biloba leaves using E. cristatum for the production of fermented feed was investigated for the first time. The idea that E. cristatum could effectively ferment tea leaves was hypothesized to be transferrable to ginkgo leaves. The results demonstrated that E. cristatum could grow on pure G. biloba leaves and the addition of excipients could significantly improve the growth of Eurotium cristatum. The results showed that G. biloba leaves fermented by E. cristatum were promising as a fermented feed.

\section{Materials and Methods}

\subsection{Materials}

The fresh G. biloba leaves obtained from Chinese Herb Transaction Center (Bozhou, China) were picked from August to September. The excipients (G. biloba seeds, corn, rice bran, soybean, barley, wheat) were purchased from Nanjing Guoyao Biotechnology Co. Ltd. (Nanjing, China). The leaves that were prepared by removing the stems and yellow leaves and excipients were dried in an oven at $40{ }^{\circ} \mathrm{C}$ for $24 \mathrm{~h}$ and at $60{ }^{\circ} \mathrm{C}$ for $12 \mathrm{~h}$, respectively, and then were pulverized to 40 mesh using a disintegrator. As for G. biloba seeds, one part was pulverized with hulls (whole G. biloba seeds), another was pulverized by removing hulls. Potato dextrose agar medium (PDA) was purchased from Qingdao Gaokeyuan Haibo Biotechnology Co. Ltd. (Qingdao, China). E. cristatum was deposited in the Fermented Food Laboratory of Nanjing Forestry University. All other chemicals used in this study were of analytical grade and commercially available.

\subsection{Preparation of Spore Suspension of Eurotium cristatum}

To activate Eurotium cristatum, the strain stored at $-20{ }^{\circ} \mathrm{C}$ was plated on PDA medium, then cultured under constant temperature $\left(28^{\circ} \mathrm{C}\right)$ and humidity $(85 \%)$ until the plate was covered with golden hyphae (about $72 \mathrm{~h}$ ). Then, the golden colony of the edge was picked and inoculated into fresh PDA medium. The above operations were repeated 2-3 times. 
The activated strains were picked and transferred to a $100 \mathrm{~mL}$ triangular flask containing sterile water and several glass beads, then shaken at $220 \mathrm{r} / \mathrm{min}$ for $45 \mathrm{~min}$. Spore number was calculated using a hemocytometer plate, and the concentration of the spore suspension was adjusted to $5.6 \times 10^{6} \mathrm{CFU} / \mathrm{mL}$.

\subsection{Prefermentation}

Preparation of G. biloba leaves medium: $8.5 \mathrm{~g}$ of G. biloba leaves powder was mixed with $10 \mathrm{~g}$ of deionized water in a $100 \mathrm{~mL}$ triangular flask. The mixture was sterilized by autoclaving at $121^{\circ} \mathrm{C}$ for 20 min to obtain a solid fermentation medium of G. biloba leaves.

In order to determine whether E. cristatum could grow on pure G. biloba leaves medium without adding any excipients, $850 \mu \mathrm{L}$ of spore suspension was inoculated into the pure medium, then cultured at $28{ }^{\circ} \mathrm{C}$ and relative humidity $85 \%$. The relevant parameters were determined after three days, five days, and seven days to investigate the growth of E. cristatum.

\subsection{Optimization of Fermentation Medium Components}

Ten percent (excipient weight/G. biloba leaves weight) of powder of G. biloba seeds, corn, rice bran, soybean, barley, or wheat were employed as excipients to the G. biloba leaves medium mentioned above. Based on the optimal auxiliary material, the addition amount of excipients was further investigated at $2 \%, 6 \%, 10 \% 14 \%, 18 \%(w / w)$. The other fermentation conditions and operations were as described in Section 2.3.

\subsection{Optimization of Fermentation Conditions}

After obtaining the optimal excipient and its optimal addition amount, the effects of different $\mathrm{pH}$ values $\left(3.0,3.5,4.0,4.5\right.$, and 5.0), inoculum size $\left(2.38 \times 10^{6}, 4.76 \times 10^{6}, 7.14 \times 10^{6}, 9.52 \times 10^{6}\right.$, and $\left.11.9 \times 10^{6} \mathrm{CFU}\right)$, water content $(35,45,55,65$, and $75 \% / 100 \mathrm{~g}$ wet medium, the water content of $G$. biloba leaves was about 10\%), and fermentation time $(1,2,3,4,5,6,7,8$, and 9 days) on the growth of E. cristatum were further optimized. In these cases, phosphate buffer instead of ultrapure water was added to the medium. The other operations and fermentation conditions were as described in Section 2.3.

\subsection{Determination of Spore Number in the Solid-State Culture}

In order to obtain a spore suspension of E. cristatum, $0.1 \mathrm{~g}$ of culture was mixed with $10 \mathrm{~mL}$ of sterile water in a $50 \mathrm{~mL}$ triangular flask containing 10 glass beads and then shaken at $28^{\circ} \mathrm{C}$ and $220 \mathrm{rpm}$ for $45 \mathrm{~min}$ in a thermostatic shaker. Next, $5 \mu \mathrm{L}$ of the diluted spore suspension was pipetted into a hemocytometer, and a drop of Medan stain was added. The spore number was measured by microscopy.

\subsection{Determination of Physicochemical Components and Enzyme Activity}

The content of TTLs was determined according to the method developed in our previous work [20]. The content of PAC, flavonoids, and PPAs was determined according to the method developed in our previous work [21]. The content of ginkgolic acids was determined according to the method described by Li et al. [22]. The content of free amino acids (FAAs) was determined according to the National Standard of the People's Republic of China (GB/T8314-2013) [23]. The content of proteins was determined by the Bradford method [24]. The content of reducing sugars was determined by anthrone colorimetry [25]. The lignin content was determined according to the method described by Zhao et al. [26]. The aroma components were determined by GC-MS method [27]. The antioxidant activity was determined according to the method described by Cao et al. [28]. The enzyme activities, including amylase, protease, lipase, pectase, cellulase, and hemicellulase, were determined according to the National Standard of the People's Republic of China (GB1886.174-2016) [29]. 


\subsection{Statistical Analysis}

The statistical analysis was carried out in the one-way ANOVA program of the SAS system for Windows 8.02 (SAS Institute Inc., Cary, NC, USA). Duncan's multiple-range test was selected as the comparison method in the program and the significance level was set at 0.05 .

\section{Results and Discussion}

\subsection{Prefermentation of Pure G. biloba Leaves with E. cristatum}

E. cristatum is the dominant fungi species isolated from Fuzhuan Brick Tea, a traditional Chinese food, which is usually applied as a probiotic for human health [11]. Thus, the fungal strain possesses potential advantages for use in the food and feed industry due to its high safety. To determine whether E. cristatum could grow on pure G. biloba leaf medium, the spore suspension of E. cristatum was inoculated into the medium, then the spore number, the content of flavonoids, and enzyme activity as the main indexes were investigated. The contents of TTLs and PAC as the auxiliary indexes were also determined. Figure 1A showed that E. cristatum could grow on pure G. biloba leaf powder, which indicated that G. biloba leaves contain appropriate carbon and nitrogen sources for the growth of $E$. cristatum. However, the spore number of E. cristatum decreased in the last two days of fermentation. This suggested that the nutrients of G. biloba leaf powder had been consumed by E. cristatum. Therefore, it was necessary to add additional carbon and nitrogen sources to maintain the growth of E. cristatum. During the fermentation, the content of TTLs had no significant change. The content of PAC kept decreasing and the terminal content was $0.12 \mathrm{mg} / \mathrm{g}$. The PAC content in G. biloba leaves originally should be $4-12 \%$ [30]. The cause of decline might be that PAC was easily oxidized and decomposed under natural conditions [31]. The content of flavonoids went up gradually, possibly because $E$. cristatum could produce flavonoids by itself or might transform the polysaccharides of G. biloba leaves to flavonoids [32].

As roughage, G. biloba leaves contain proteins and crude fibers such as cellulose, hemicellulose, pectin, and lignin. It is difficult for animals to assimilate these components by themselves [16]. E. cristatum can secrete abundant enzymes to degrade these macromolecular substances in their metabolic processes, thus investigating the changes of several typical enzymes' activities in the process of fermentation is necessary. The results are shown in Figure 1B. The activities of cellulase, hemicellulase, and pectase greatly increased up to $1952.7 \mathrm{U} / \mathrm{g}, 1696.1 \mathrm{U} / \mathrm{g}$, and $3935.0 \mathrm{U} / \mathrm{g}$ on the third day, respectively. These enzymes work to reduce the lignocellulose content of $G$. biloba leaves and can be very beneficial to animal digestion of lignocellulose. Compared with other enzymes, the amylase activity was lower but relatively stable, maintaining at about $4.6 \mathrm{U} / \mathrm{g}$. The other five enzymes' activities showed decreases with the extension of fermentation time. At the end of fermentation, the protease, lipase, pectase, cellulase, and hemicellulase activity decreased by $20.8 \%, 56.9 \%, 46.8 \%, 37.6 \%$, and $86.2 \%$, respectively. Due to the limited nutrients in the pure G. biloba leaves, in the late stage of fermentation, the strain's growth viability began to degenerate with the reducing spore number. As a result, the secretion of enzymes also declined. Thus, the ability of E. cristatum to grow on pure G. biloba leaves was restricted. To further promote the growth of E. cristatum for degrading crude fibers and improving the nutrients of feed, it is necessary to add additional carbon and nitrogen sources into G. biloba leaf medium. 

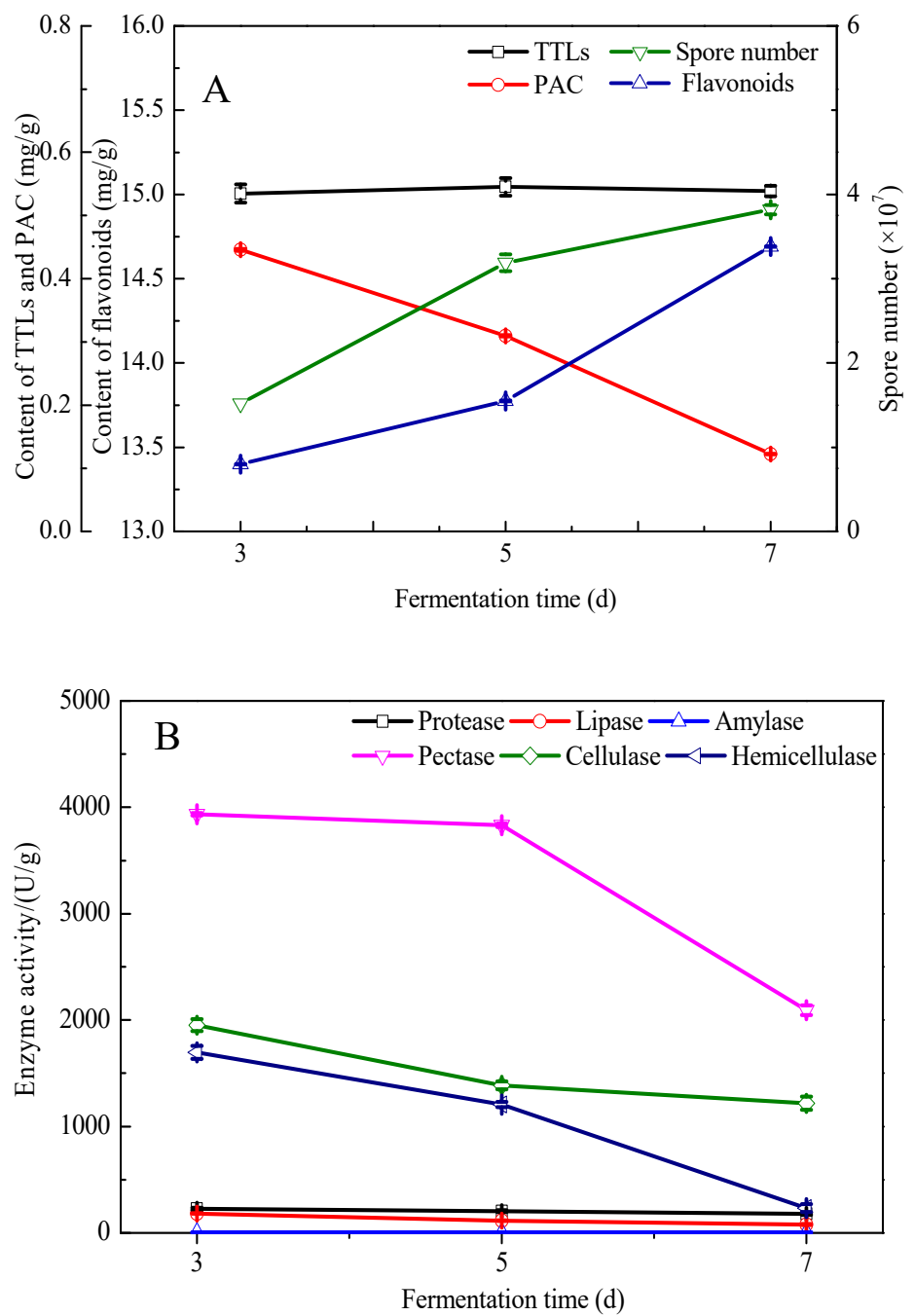

Figure 1. Changes of different indexes: (A) spore number, terpene trilactones (TTLs), procyanidine (PAC), and flavonoids; and (B) activities of different enzymes during the prefermentation of pure G. biloba leaf powder with Eurotium cristatum.

\subsection{Fermentation of G. biloba Leaves with Addition of Excipients}

Considering the cost and safety of the final product, several commonly used excipients for feed were added to the G. biloba leaf powder for promoting the fermentation of E. cristatum. As shown in Table 1, comparison of the spore number indicated the effect of different excipients, in the order of $G$. biloba seeds, maize, rice bran, wheat, whole G. biloba seeds, soybean meal, and barley. TTLs are usually very low (0.001-0.8\%) in G. biloba leaves [33]. The TTLs content remained stable at about $0.65 \mathrm{mg} / \mathrm{g}$ during fermentation, which showed that the E. cristatum could not consume it. The variation tendency of PAC was similar to that in the prefermentation. The content of flavonoids increased more obviously than that in the prefermentation. When wheat was added as an excipient, the content of flavonoids reached the highest value. When soybean meal, whole G. biloba seeds, barley, and maize were added, the content of flavonoids remained at the same level. Moreover, when G. biloba seeds and rice bran were used as excipients, the content of flavonoids was slightly lower. There might be two reasons that brought about the distinction of the content of flavonoids between different excipients. Firstly, owing to the addition of excipients, the spore number of E. cristatum increased by nearly 10 times, thus the strains might metabolically synthesize a certain amount of flavonoids. Secondly, different kinds of excipients might also contain different amounts of flavonoids. Regardless of the kind of excipient employed, the content of flavonoids decreased in the prophase of fermentation, possibly 
because E. cristatum secreted some extracellular enzymes which could oxidize and degrade flavonoids. However, E. cristatum might produce pigments or flavonoids at the same time [27]. Thus, in anaphase of fermentation, the content of flavonoids maintained an upward trend with the significant increment of spore number. Nevertheless, flavonoids can be consumed as substances when Aspergillus niger is used as the strain to ferment ginkgo leaves [34], which suggested that E. cristatum fermentation is more advantageous for enhancing the flavonoid content of the media than A. niger.

Table 1. Effects of the excipients on the spore number, TTLS, PAC, and flavonoids in the fermented G. biloba leaves.

\begin{tabular}{|c|c|c|c|c|c|}
\hline Excipient & Time (d) & $\begin{array}{l}\text { Spore Number } \\
\left(\times 10^{8} \mathrm{CFU}\right)\end{array}$ & TTLs (mg/g) & PAC (mg/g) & $\begin{array}{l}\text { Flavonoids } \\
\text { (mg/g) }\end{array}$ \\
\hline \multirow{3}{*}{ Maize } & 3 & $1.05 \pm 0.04^{\mathrm{n}}$ & $0.62 \pm 0.02^{\mathrm{c}}$ & $0.05 \pm 0.01 \mathrm{~g}$ & $24.98 \pm 0.03^{e}$ \\
\hline & 5 & $2.44 \pm 0.03^{e}$ & $0.63 \pm 0.02^{b c}$ & $0.09 \pm 0.02^{f}$ & $23.44 \pm 0.01^{\mathrm{g}}$ \\
\hline & 7 & $2.75 \pm 0.03^{c}$ & $0.62 \pm 0.03^{b c}$ & $0.04 \pm 0.02^{g}$ & $25.32 \pm 0.03^{d}$ \\
\hline \multirow{3}{*}{ Rice bran } & 3 & $1.25 \pm 0.02^{\mathrm{m}}$ & $0.66 \pm 0.01^{b}$ & $0.24 \pm 0.03^{c}$ & $18.11 \pm 0.03^{j}$ \\
\hline & 5 & $2.22 \pm 0.04^{f}$ & $0.65 \pm 0.02^{b c}$ & $0.24 \pm 0.02^{c}$ & $16.15 \pm 0.01^{\mathrm{k}}$ \\
\hline & 7 & $2.47 \pm 0.01^{\mathrm{de}}$ & $0.65 \pm 0.01^{b c}$ & $0.14 \pm 0.01^{\mathrm{de}}$ & $19.48 \pm 0.01^{h i}$ \\
\hline \multirow{3}{*}{ Soybean meal } & 3 & $0.91 \pm 0.01 \mathrm{o}$ & $0.62 \pm 0.01^{\mathrm{c}}$ & $0.09 \pm 0.04^{\mathrm{f}}$ & $25.78 \pm 0.01^{\mathrm{d}}$ \\
\hline & 5 & $1.73 \pm 0.03^{\mathrm{k}}$ & $0.61 \pm 0.01^{\mathrm{c}}$ & $0.12 \pm 0.02^{\text {de }}$ & $24.69 \pm 0.01^{\mathrm{e}}$ \\
\hline & 7 & $1.93 \pm 0.02^{\mathrm{i}}$ & $0.62 \pm 0.01^{c}$ & $0.12 \pm 0.01^{\mathrm{de}}$ & $26.65 \pm 0.04^{c}$ \\
\hline \multirow{3}{*}{ Barely } & 3 & $0.61 \pm 0.01 \mathrm{q}$ & $0.65 \pm 0.02^{b c}$ & $0.16 \pm 0.01^{\mathrm{d}}$ & $24.28 \pm 0.05^{f}$ \\
\hline & 5 & $1.58 \pm 0.04^{1}$ & $0.64 \pm 0.01^{b c}$ & $0.16 \pm 0.02^{d}$ & $23.69 \pm 0.01^{g}$ \\
\hline & 7 & $1.85 \pm 0.01^{\mathrm{j}}$ & $0.65 \pm 0.01^{b c}$ & $0.04 \pm 0.04^{h}$ & $24.82 \pm 0.01^{d}$ \\
\hline \multirow{3}{*}{ Wheat } & 3 & $0.93 \pm 0.02^{\circ}$ & $0.65 \pm 0.01^{b c}$ & $0.39 \pm 0.03^{\mathrm{a}}$ & $29.32 \pm 0.09^{a}$ \\
\hline & 5 & $2.03 \pm 0.02^{g}$ & $0.65 \pm 0.01^{b c}$ & $0.28 \pm 0.01^{\mathrm{b}}$ & $26.61 \pm 0.05^{\mathrm{c}}$ \\
\hline & 7 & $2.52 \pm 0.04^{\mathrm{d}}$ & $0.66 \pm 0.01^{b}$ & $0.29 \pm 0.08^{\mathrm{ab}}$ & $27.98 \pm 0.02^{b}$ \\
\hline \multirow{3}{*}{$\begin{array}{l}\text { Whole G. biloba } \\
\text { seeds }\end{array}$} & 3 & $0.80 \pm 0.01^{p}$ & $0.60 \pm 0.01^{\mathrm{c}}$ & $0.21 \pm 0.03^{c}$ & $25.86 \pm 0.03^{\mathrm{d}}$ \\
\hline & 5 & $1.90 \pm 0.03^{\mathrm{i}}$ & $0.62 \pm 0.01^{\mathrm{c}}$ & $0.11 \pm 0.02^{\mathrm{e}}$ & $24.15 \pm 0.01^{\mathrm{f}}$ \\
\hline & 7 & $2.02 \pm 0.03^{g}$ & $0.61 \pm 0.01^{\mathrm{c}}$ & $0.04 \pm 0.01^{g}$ & $27.65 \pm 0.01^{b}$ \\
\hline \multirow{3}{*}{ G. biloba seeds } & 3 & $1.87 \pm 0.02^{\mathrm{j}}$ & $0.72 \pm 0.01^{\mathrm{a}}$ & $0.34 \pm 0.04^{\mathrm{a}}$ & $19.19 \pm 0.01^{\mathrm{i}}$ \\
\hline & 5 & $2.90 \pm 0.01^{b}$ & $0.73 \pm 0.01^{\mathrm{a}}$ & $0.34 \pm 0.01^{\mathrm{a}}$ & $18.11 \pm 0.04^{\mathrm{j}}$ \\
\hline & 7 & $3.10 \pm 0.04^{\mathrm{a}}$ & $0.72 \pm 0.01^{\mathrm{a}}$ & $0.36 \pm 0.02^{\mathrm{a}}$ & $19.78 \pm 0.01^{h}$ \\
\hline
\end{tabular}

Note: Different lowercase letters in the same column indicate that the values are significantly different $(\alpha=0.05)$.

During ginkgo leaves fermentation by $A$. niger with wheat bran and corncob used as additives, significantly higher enzyme activity was obtained than in the control fermentation [35]. Thus, the addition of excipients had important impacts on enzyme activity. However, these additives also greatly increased the cellulose content of feed, which is an antinutritive factor for monogastric animals. In this study, other additives were used for improving enzymatic activity and full-scale enzyme activities were investigated. As shown in Table 2, enzyme activity positively correlated with the spore number during fermentation. The activity of several enzymes was at a higher level when whole G. biloba seeds severed as excipients. The activities of pectinase, cellulase, and hemicellulase were remarkably increased when G. biloba seeds were added, and the lipase activity was the highest while rice bran was used. The protease activity was always high no matter what kind of excipients were added. For animals, the presence of cellulase and hemicellulase is beneficial for the degradation of cellulose in the feed to reduce the risk of gastrointestinal disease. Lipase can inhibit the absorption of fat and prevent abnormal obesity to keep the animals healthy. Protease breaks down protein into small amino acids and peptides to enable digestion and absorption. Moreover, the presence of enzymes induces the depolymerization of macromolecule constituents, which improves the nutritional and flavor quality of ginkgo leaves [27]. 
Table 2. Effects of the excipients on the activities of several enzymes in fermented G. biloba leaves.

\begin{tabular}{|c|c|c|c|c|c|c|c|}
\hline \multirow{2}{*}{ Excipient } & \multirow{2}{*}{ Time (d) } & \multicolumn{6}{|c|}{ Enzyme Activity (U/g) } \\
\hline & & Amylase & Lipase & Protease & Pectinase & Cellulase & Hemicellulase \\
\hline \multirow{4}{*}{ Maize } & 3 & $4.67 \pm 0.01^{\mathrm{a}}$ & $142.22 \pm 2.06^{\mathrm{e}}$ & $336.69 \pm 9.93^{\mathrm{fg}}$ & $5586.39 \pm 4.81^{\mathrm{d}}$ & $2900.75 \pm 74.39^{b}$ & $4136.11 \pm 31.82^{\mathrm{c}}$ \\
\hline & 5 & $4.65 \pm 0.01^{\mathrm{ab}}$ & $98.52 \pm 1.22^{\mathrm{h}}$ & $314.07 \pm 9.49^{h}$ & $5572.50 \pm 30.05^{\mathrm{d}}$ & $2133.14 \pm 25.05^{f}$ & $2920.83 \pm 41.67^{\mathrm{h}}$ \\
\hline & 7 & $4.65 \pm 0.02^{\mathrm{ab}}$ & $73.33 \pm 0.89 j$ & $190.06 \pm 6.62^{1}$ & $4900.28 \pm 76.98 \mathrm{~g}$ & $845.38 \pm 66.17^{1}$ & $927.78 \pm 52.43^{\mathrm{m}}$ \\
\hline & 3 & $4.68 \pm 0.01^{\mathrm{a}}$ & $124.44 \pm 1.82^{f}$ & $317.64 \pm 10.96^{\mathrm{h}}$ & $5094.72 \pm 41.94^{\mathrm{f}}$ & $1804.89 \pm 91.42^{\mathrm{gh}}$ & $3663.89 \pm 63.65^{\mathrm{e}}$ \\
\hline \multirow[t]{2}{*}{ Rice bran } & 5 & $4.65 \pm 0.01^{\mathrm{ab}}$ & $103.70 \pm 1.88$ & $307.12 \pm 6.18^{\mathrm{hi}}$ & $4641.94 \pm 19.25^{\mathrm{h}}$ & $1219.08 \pm 58.07^{j}$ & $2233.33 \pm 55.12^{j}$ \\
\hline & 7 & $4.64 \pm 0.01^{\mathrm{bc}}$ & $93.33 \pm 0.35^{\mathrm{i}}$ & $199.78 \pm 9.49^{1}$ & $3203.06 \pm 4.81^{\mathrm{k}}$ & $582.77 \pm 74.39^{\mathrm{m}}$ & $573.61 \pm 31.82^{\mathrm{n}}$ \\
\hline \multirow{4}{*}{$\begin{array}{l}\text { Soybean } \\
\text { meal }\end{array}$} & 3 & $4.67 \pm 0.02^{\mathrm{a}}$ & $182.22 \pm 0.97^{b}$ & $327.86 \pm 12.10^{\mathrm{gh}}$ & $5697.50 \pm 41.67^{\mathrm{d}}$ & $1850.34 \pm 118.45^{\mathrm{g}}$ & $4962.50 \pm 55.12^{\mathrm{b}}$ \\
\hline & 5 & $4.64 \pm 0.03^{\mathrm{abc}}$ & $93.33 \pm 2.05^{\mathrm{i}}$ & $321.81 \pm 6.18^{g h}$ & $5711.39 \pm 24.06^{\mathrm{d}}$ & $1567.53 \pm 43.05^{j}$ & $3761.11 \pm 12.03^{\mathrm{d}}$ \\
\hline & 7 & $4.64 \pm 0.04^{\mathrm{abc}}$ & $53.33 \pm 1.22^{\mathrm{j}}$ & $258.51 \pm 9.99^{\mathrm{k}}$ & $4594.72 \pm 12.73^{h}$ & $719.13 \pm 97.53^{\mathrm{m}}$ & $1177.78 \pm 52.43^{1}$ \\
\hline & 3 & $4.63 \pm 0.02^{\mathrm{bc}}$ & $195.55 \pm 2.12^{\mathrm{a}}$ & $377.56 \pm 8.09^{\mathrm{bc}}$ & $4111.39 \pm 20.97^{\mathrm{i}}$ & $2436.14 \pm 133.32^{\mathrm{e}}$ & $3268.06 \pm 52.43 \mathrm{~g}$ \\
\hline \multirow[t]{2}{*}{ Barely } & 5 & $4.60 \pm 0.01^{\mathrm{c}}$ & $127.41 \pm 1.94^{\mathrm{f}}$ & $371.81 \pm 5.63^{c}$ & $3994.72 \pm 31.55^{\mathrm{i}}$ & $1804.89 \pm 62.57^{\mathrm{g}}$ & $2316.67 \pm 72.17 j$ \\
\hline & 7 & $4.59 \pm 0.06^{\mathrm{c}}$ & $94.81 \pm 2.06^{\mathrm{hi}}$ & $359.90 \pm 9.75^{\mathrm{de}}$ & $3122.50 \pm 8.33^{1}$ & $1264.53 \pm 64.46^{j}$ & $184.72 \pm 12.03^{\circ}$ \\
\hline \multirow{3}{*}{ Wheat } & 3 & $4.64 \pm 0.03^{\mathrm{abc}}$ & $148.15 \pm 2.91^{d}$ & $360.50 \pm 8.33^{\mathrm{de}}$ & $5108.61 \pm 9.62^{f}$ & $2678.54 \pm 42.15^{c}$ & $3400.00 \pm 20.83^{f}$ \\
\hline & 5 & $4.63 \pm 0.01^{\mathrm{bc}}$ & $120.00 \pm 1.22 \mathrm{~g}$ & $291.25 \pm 9.11^{\mathrm{i}}$ & $4833.61 \pm 75.61^{g}$ & $1703.89 \pm 35.03^{h}$ & $1420.83 \pm 20.83^{\mathrm{k}}$ \\
\hline & 7 & $4.62 \pm 0.01^{\mathrm{bc}}$ & $56.30 \pm 0.46^{\mathrm{k}}$ & $262.38 \pm 8.73 j$ & $3786.39 \pm 79.20^{j}$ & $633.28 \pm 72.72^{\mathrm{m}}$ & $858.33 \pm 20.83^{\mathrm{m}}$ \\
\hline \multirow{3}{*}{$\begin{array}{l}\text { Whole G. } \\
\text { biloba seeds }\end{array}$} & 3 & $4.68 \pm 0.02^{\mathrm{a}}$ & $184.44 \pm 5.08^{b}$ & $384.11 \pm 5.78^{b}$ & $6066.94 \pm 41.11^{\mathrm{c}}$ & $2592.69 \pm 4.96^{\mathrm{d}}$ & $5191.67 \pm 83.33^{b}$ \\
\hline & 5 & $4.64 \pm 0.05^{\mathrm{ac}}$ & $139.26 \pm 2.05^{\mathrm{e}}$ & $361.29 \pm 7.03^{\mathrm{d}}$ & $5644.72 \pm 127.29^{d}$ & $1284.73 \pm 21.90^{j}$ & $2747.22 \pm 86.74^{\mathrm{i}}$ \\
\hline & 7 & $4.64 \pm 0.01^{\mathrm{bc}}$ & $97.78 \pm 1.22^{\mathrm{hi}}$ & $343.63 \pm 8.84^{\mathrm{ef}}$ & $4830.83 \pm 8.33^{g}$ & $890.83 \pm 8.06^{1}$ & $1163.89 \pm 43.37^{1}$ \\
\hline \multirow{3}{*}{$\begin{array}{l}\text { G. biloba } \\
\text { seeds }\end{array}$} & 3 & $4.60 \pm 0.02^{\mathrm{c}}$ & $186.67 \pm 5.56^{\mathrm{ab}}$ & $398.99 \pm 6.62^{\mathrm{a}}$ & $6789.17 \pm 22.05^{\mathrm{a}}$ & $3183.55 \pm 4.96^{\mathrm{a}}$ & $5629.17 \pm 75.12^{\mathrm{a}}$ \\
\hline & 5 & $4.59 \pm 0.01^{\mathrm{c}}$ & $164.44 \pm 2.05^{\mathrm{c}}$ & $373.39 \pm 12.52^{\mathrm{bc}}$ & $6578.06 \pm 45.90^{\mathrm{b}}$ & $1658.44 \pm 4.96^{\mathrm{i}}$ & $2920.83 \pm 90.81^{\mathrm{h}}$ \\
\hline & 7 & $4.57 \pm 0.03^{c}$ & $166.68 \pm 3.22^{\mathrm{c}}$ & $346.61 \pm 7.54^{\mathrm{ef}}$ & $5214.17 \pm 41.67^{\mathrm{e}}$ & $951.43 \pm 12.12^{\mathrm{k}}$ & $1462.50 \pm 126.72^{\mathrm{k}}$ \\
\hline
\end{tabular}

Note: Different lowercase letters in the same column indicate that the values are significantly different $(\alpha=0.05)$. 
Considering the cost of feed and comprehensive results of various indicators, whole G. biloba seeds were chosen as an excipient, and their addition amount was further optimized. Ten percent $(w / w)$ was the optimal addition amount in terms of spore number and flavonoid content (Figure 2A,B). Table 3 shows that significant increments of six enzymes' activities were observed with increasing excipient from $2 \%$ to $10 \%(w / w)$. However, continued excipient increase led to a loss of enzyme activity. Thus, combining the spore number with the activity of several enzymes, $10 \%(w / w)$ was eventually selected as the optimal addition amount of whole G. biloba seeds.
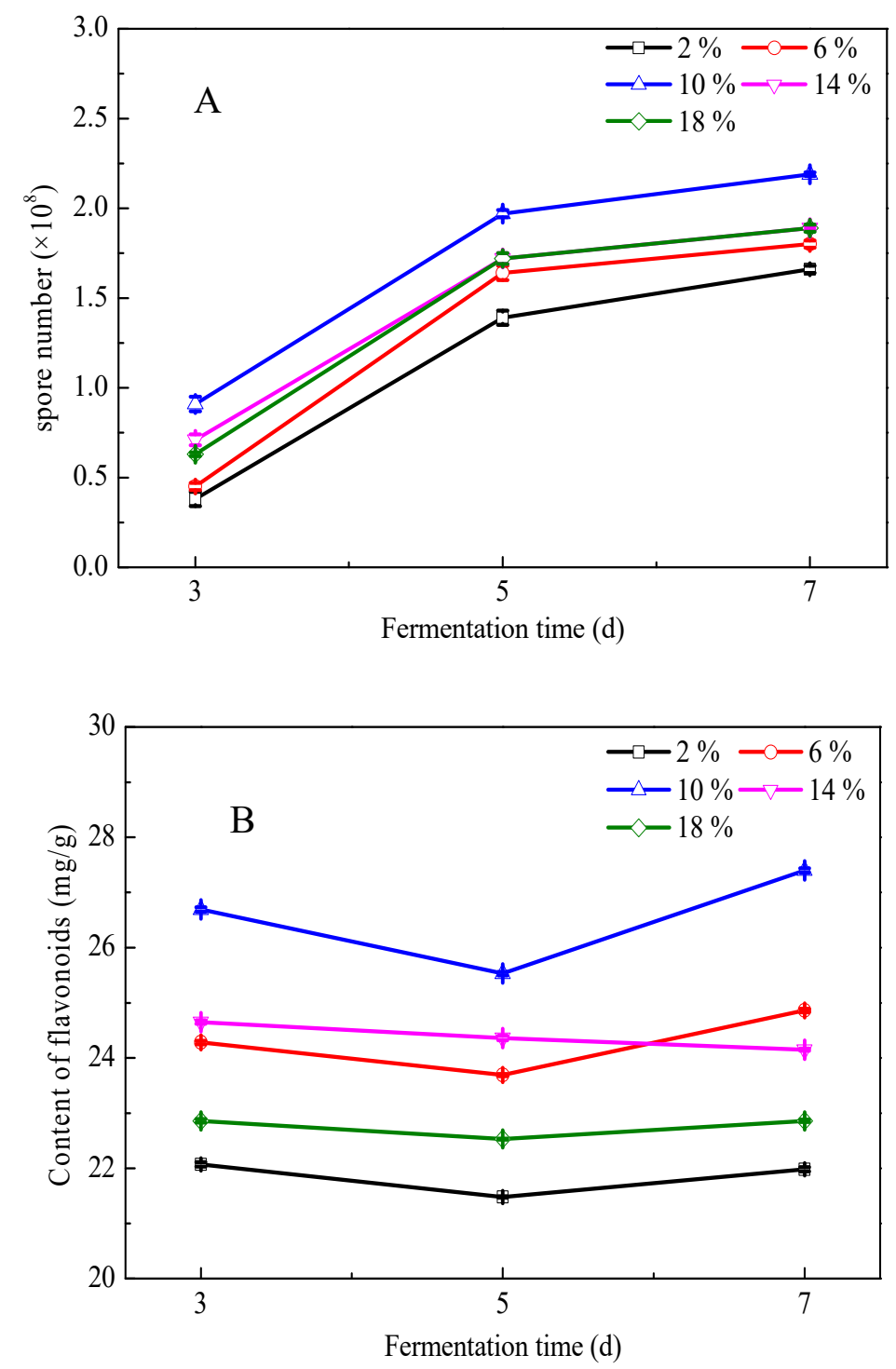

Figure 2. Effects of varying amounts of whole G. biloba seeds $(\%, w / w)$ on (A) spore number and (B) flavonoid content. 
Table 3. Effects of varying amounts of whole G. biloba seeds on the activities of several enzymes in fermented G. biloba leaves.

\begin{tabular}{|c|c|c|c|c|c|c|c|}
\hline \multirow{2}{*}{$\begin{array}{c}\text { Whole G. biloba } \\
\text { Seeds }(\%, w / w)\end{array}$} & \multirow{2}{*}{ Time (d) } & \multicolumn{6}{|c|}{ Enzyme Activity (U/g) } \\
\hline & & Amylase & Lipase & Protease & Pectinase & Cellulase & Hemicellulase \\
\hline \multirow{4}{*}{2} & 3 & $4.40 \pm 0.01^{\mathrm{f}}$ & $124.44 \pm 4.15^{\mathrm{d}}$ & $287.88 \pm 6.76^{\mathrm{d}}$ & $4091.94 \pm 5.24^{\mathrm{k}}$ & $832.25 \pm 31.54^{1}$ & $1504.17 \pm 36.08^{k}$ \\
\hline & 5 & $4.40 \pm 0.01^{\mathrm{f}}$ & $108.89 \pm 2.90^{\mathrm{e}}$ & $292.04 \pm 5.85^{d}$ & $4169.72 \pm 19.25^{j}$ & $640.35 \pm 8.75^{\mathrm{m}}$ & $1344.44 \pm 12.03^{1}$ \\
\hline & 7 & $4.39 \pm 0.01^{\mathrm{f}}$ & $83.71 \pm 0.98^{\mathrm{i}}$ & $293.43 \pm 5.85^{\mathrm{d}}$ & $4189.17 \pm 11.02^{j}$ & $539.35 \pm 15.15^{\mathrm{n}}$ & $1212.50 \pm 19.82^{\mathrm{m}}$ \\
\hline & 3 & $4.51 \pm 0.02^{\mathrm{c}}$ & $148.15 \pm 5.34^{\mathrm{c}}$ & $315.85 \pm 5.28^{c}$ & $4880.83 \pm 2.08^{g}$ & $1700.86 \pm 23.14^{\mathrm{g}}$ & $2295.83 \pm 21.11^{g}$ \\
\hline \multirow[t]{3}{*}{6} & 5 & $4.52 \pm 0.01^{\mathrm{c}}$ & $120.00 \pm 2.36^{\mathrm{d}}$ & $314.46 \pm 6.52^{c}$ & $4872.50 \pm 2.08^{g}$ & $1599.85 \pm 15.15^{\mathrm{h}}$ & $2156.94 \pm 18.13^{\mathrm{i}}$ \\
\hline & 7 & $4.52 \pm 0.02^{\mathrm{C}}$ & $100.00 \pm 1.04^{\mathrm{f}}$ & $314.46 \pm 5.97^{c}$ & $4922.50 \pm 3.61^{\mathrm{f}}$ & $1296.85 \pm 15.15^{\mathrm{k}}$ & $1990.28 \pm 31.82^{j}$ \\
\hline & 3 & $4.62 \pm 0.02^{\mathrm{a}}$ & $192.59 \pm 1.78^{\mathrm{a}}$ & $378.35 \pm 5.63^{\mathrm{a}}$ & $6014.17 \pm 2.08^{c}$ & $2933.07 \pm 15.15^{\mathrm{a}}$ & $4997.22 \pm 25.89^{a}$ \\
\hline \multirow[t]{3}{*}{10} & 5 & $4.60 \pm 0.03^{\mathrm{ab}}$ & $140.00 \pm 2.93^{c}$ & $374.78 \pm 6.76^{\mathrm{a}}$ & $6080.83 \pm 5.51^{b}$ & $2549.26 \pm 38.13^{b}$ & $4281.94 \pm 45.91^{\mathrm{b}}$ \\
\hline & 7 & $4.61 \pm 0.04^{\mathrm{ab}}$ & $102.22 \pm 2.36^{\mathrm{f}}$ & $377.96 \pm 5.63^{\mathrm{a}}$ & $6166.94 \pm 1.20^{\mathrm{a}}$ & $2347.26 \pm 31.54^{\mathrm{c}}$ & $3677.78 \pm 104.17^{\mathrm{d}}$ \\
\hline & 3 & $4.58 \pm 0.03^{\mathrm{ab}}$ & $174.07 \pm 2.36^{\mathrm{b}}$ & $343.83 \pm 6.32^{b}$ & $5272.50 \pm 4.17^{\mathrm{e}}$ & $2306.86 \pm 8.75^{c}$ & $4316.67 \pm 73.49^{b}$ \\
\hline \multirow[t]{3}{*}{14} & 5 & $4.56 \pm 0.01^{\mathrm{b}}$ & $128.89 \pm 1.04^{c}$ & $336.09 \pm 6.18^{b}$ & $5250.28 \pm 7.89^{e}$ & $2024.06 \pm 30.30^{\mathrm{e}}$ & $3941.67 \pm 67.90^{c}$ \\
\hline & 7 & $4.57 \pm 0.01^{\mathrm{b}}$ & $95.56 \pm 5.34^{\mathrm{g}}$ & $339.27 \pm 6.85^{b}$ & $5341.94 \pm 1.20^{\mathrm{d}}$ & $1912.96 \pm 8.75^{f}$ & $3525.00 \pm 43.37^{\mathrm{e}}$ \\
\hline & 3 & $4.46 \pm 0.04^{\mathrm{d}}$ & $142.96 \pm 5.34^{\mathrm{c}}$ & $299.19 \pm 8.22^{\mathrm{d}}$ & $4608.61 \pm 3.18^{h}$ & $1700.86 \pm 8.75^{g}$ & $3677.78 \pm 20.83^{d}$ \\
\hline \multirow[t]{2}{*}{18} & 5 & $4.46 \pm 0.02^{\mathrm{d}}$ & $120.74 \pm 2.36^{\mathrm{d}}$ & $297.40 \pm 6.76^{d}$ & $4525.28 \pm 4.81^{\mathrm{i}}$ & $1620.05 \pm 8.75^{\mathrm{h}}$ & $2983.33 \pm 31.93^{f}$ \\
\hline & 7 & $4.45 \pm 0.01^{\mathrm{e}}$ & $88.15 \pm 1.21^{\mathrm{h}}$ & $298.99 \pm 6.13^{d}$ & $4555.83 \pm 3.61^{\mathrm{i}}$ & $1559.45 \pm 8.75^{j}$ & $2288.89 \pm 21.34^{g}$ \\
\hline
\end{tabular}

Note: Different lowercase letters in the same column indicate that the values are significantly different $(\alpha=0.05)$. 


\subsection{Effects of Fermentation Conditions}

The $\mathrm{pH}$ of the medium has strong effects on many enzymatic processes and transport of various components across the cell membrane [36]. An acidic environment is beneficial for the growth of $E$. cristatum. Liu et al. reported that E. cristatum can grow between $\mathrm{pH} 3.0$ and 6.0 [37]. In this study, the $\mathrm{pH}$ of the medium was optimized in the range of 3.0 to 5.0. The results are shown in Figure 3A,B. The spore number was significantly increased in the $\mathrm{pH}$ range from 3.0 to $4.5(\alpha=0.05)$, with the optimal $\mathrm{pH}$ being 4.5 (Figure $3 \mathrm{~A}$ ). When the $\mathrm{pH}$ increased further, the spore number decreased. The spore numbers were not significantly different between $\mathrm{pH} 4.0$ and $\mathrm{pH}$ 5.0. The content of TTLs was stable and the content of PAC was reduced as mentioned in Section 3.1. The content of flavonoids peaked at $\mathrm{pH}$ of 5 and there was no significant difference between $\mathrm{pH} 4.0$ and 4.5 in the later stage of fermentation (Figure 3B). When the $\mathrm{pH}$ was 4.5 , the content of flavonoids reached $27.78 \pm 0.03 \mathrm{mg} / \mathrm{g}$. However, an obvious decrease of flavonoids content was observed when the $\mathrm{pH}$ was 3.0 or 3.5. The content of flavonoids presented a downward trend with the advancement of fermentation. Thus, it can be speculated that flavonoids were not only related to raw materials and E. cristatum, but also the $\mathrm{pH}$ value. The acidic environment resulted in the reduction of flavonoids. The highest activity of six enzymes was achieved with a pH of 4.5 (Table 4). During the fermentation, while the extracellular enzymes were certainly influenced by the $\mathrm{pH}$ value, the activity changes of intracellular enzymes may be attributed to the variations of growth, reproduction, and metabolism of E. cristatum caused by the $\mathrm{pH}$ value. In conclusion, the optimal $\mathrm{pH}$ was set as 4.5 .
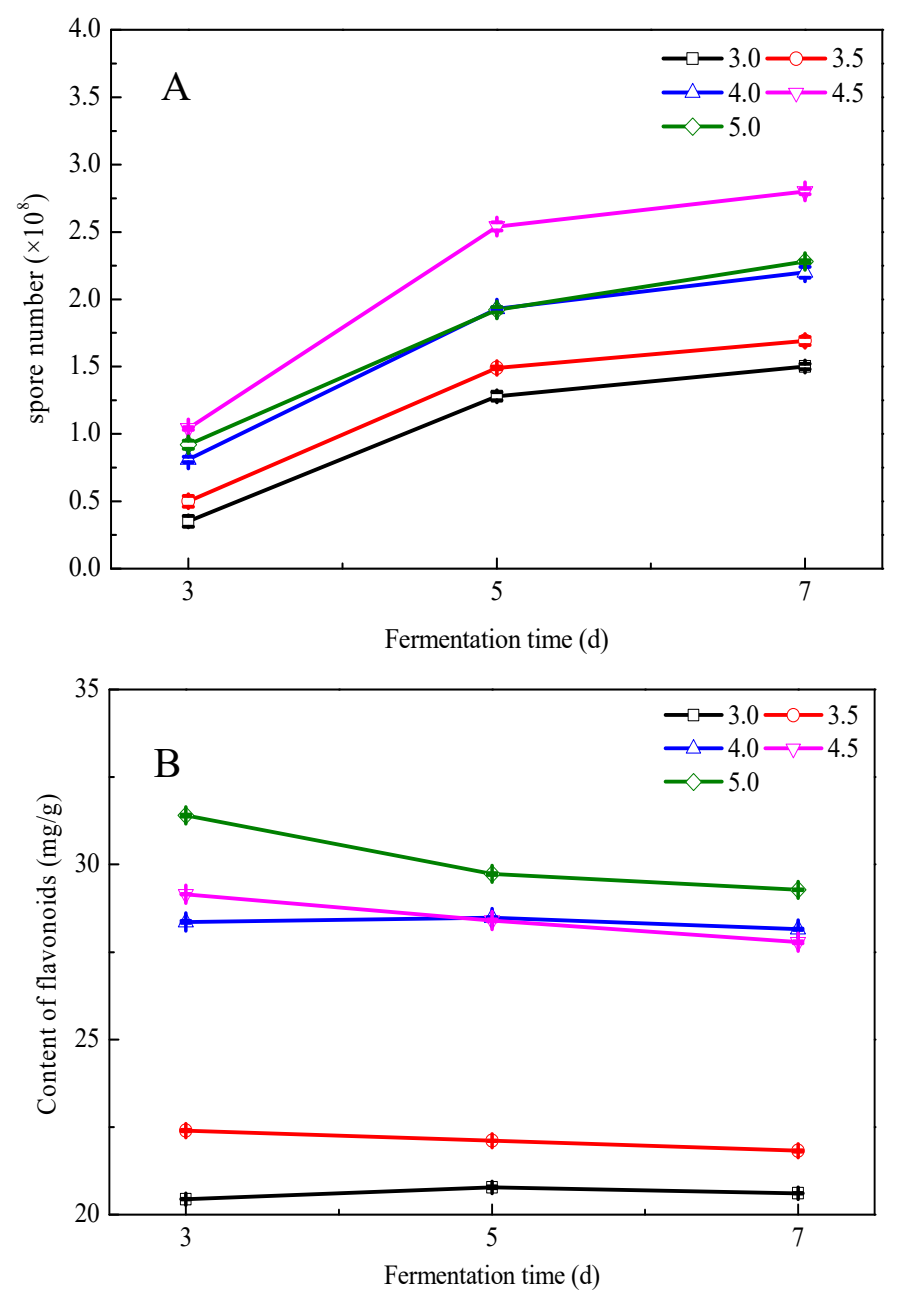

Figure 3. Effects of $\mathrm{pH}$ on different indexes: (A) spore number and (B) flavonoid content. 
Table 4. Effects of $\mathrm{pH}$ on the activities of several enzymes in fermented G. biloba leaves.

\begin{tabular}{|c|c|c|c|c|c|c|c|}
\hline \multirow{2}{*}{$\mathrm{pH}$} & \multirow{2}{*}{ Time (d) } & \multicolumn{6}{|c|}{ Enzymes Activity (U/g) } \\
\hline & & Amylase & Lipase & Protease & Pectinase & Cellulase & Hemicellulase \\
\hline \multirow{4}{*}{3} & 3 & $4.36 \pm 0.03^{c}$ & $144.44 \pm 2.22^{\mathrm{d}}$ & $316.65 \pm 5.28^{d}$ & $3800.28 \pm 29.27^{h}$ & $956.48 \pm 25.43^{f}$ & $3865.28 \pm 3.18^{h}$ \\
\hline & 5 & $4.35 \pm 0.01^{\mathrm{d}}$ & $115.56 \pm 2.22^{f}$ & $317.24 \pm 6.18^{\mathrm{d}}$ & $3755.83 \pm 8.33^{\mathrm{i}}$ & $774.68 \pm 50.87 \mathrm{~g}$ & $3573.61 \pm 5.24^{\mathrm{k}}$ \\
\hline & 7 & $4.37 \pm 0.02^{\mathrm{c}}$ & $57.78 \pm 2.22^{\mathrm{i}}$ & $314.46 \pm 5.54^{\mathrm{d}}$ & $3741.94 \pm 25.46^{\mathrm{i}}$ & $491.87 \pm 25.43^{h}$ & $3156.94 \pm 5.24^{\mathrm{m}}$ \\
\hline & 3 & $4.41 \pm 0.02^{\mathrm{c}}$ & $160.75 \pm 3.39^{c}$ & $354.94 \pm 5.54^{\mathrm{c}}$ & $4236.39 \pm 12.739$ & $1148.38 \pm 16.65^{\mathrm{d}}$ & $4212.50 \pm 2.08^{\mathrm{f}}$ \\
\hline \multirow[t]{3}{*}{3.5} & 5 & $4.41 \pm 0.04^{\mathrm{c}}$ & $123.70 \pm 3.39^{\mathrm{e}}$ & $352.36 \pm 5.63^{c}$ & $4214.17 \pm 22.05^{g}$ & $961.53 \pm 25.43^{f}$ & $3816.67 \pm 3.61^{\mathrm{i}}$ \\
\hline & 7 & $4.41 \pm 0.01^{\mathrm{c}}$ & $76.30 \pm 3.39^{h}$ & $352.76 \pm 7.03^{c}$ & $4222.50 \pm 22.05^{g}$ & $799.93 \pm 16.65^{\mathrm{g}}$ & $3115.28 \pm 7.89^{n}$ \\
\hline & 3 & $4.52 \pm 0.01^{\mathrm{b}}$ & $186.67 \pm 2.22^{b}$ & $371.41 \pm 6.85^{\mathrm{ab}}$ & $5375.28 \pm 17.35^{\mathrm{e}}$ & $1365.53 \pm 34.66^{\mathrm{c}}$ & $4754.17 \pm 2.08^{b}$ \\
\hline \multirow[t]{3}{*}{4} & 5 & $4.53 \pm 0.03^{b}$ & $146.67 \pm 2.22^{\mathrm{d}}$ & $370.81 \pm 7.03^{\mathrm{ab}}$ & $5325.28 \pm 41.11^{\mathrm{e}}$ & $1289.78 \pm 25.43^{\mathrm{d}}$ & $4358.33 \pm 4.17^{\mathrm{e}}$ \\
\hline & 7 & $4.53 \pm 0.02^{\mathrm{b}}$ & $95.56 \pm 2.22^{g}$ & $371.61 \pm 5.54^{\mathrm{ab}}$ & $5291.94 \pm 37.58^{f}$ & $981.73 \pm 16.65^{f}$ & $3740.28 \pm 9.39 j$ \\
\hline & 3 & $4.61 \pm 0.03^{\mathrm{a}}$ & $212.59 \pm 7.80^{\mathrm{a}}$ & $388.08 \pm 5.85^{\mathrm{a}}$ & $6361.39 \pm 12.73^{\mathrm{a}}$ & $1643.28 \pm 34.66^{\mathrm{a}}$ & $5191.67 \pm 4.17^{\mathrm{a}}$ \\
\hline \multirow[t]{3}{*}{4.5} & 5 & $4.60 \pm 0.01^{\mathrm{a}}$ & $182.22 \pm 2.22^{b}$ & $385.50 \pm 5.85^{\mathrm{a}}$ & $6378.06 \pm 34.69^{\mathrm{a}}$ & $1451.38 \pm 16.65^{b}$ & $4594.44 \pm 3.18^{\mathrm{d}}$ \\
\hline & 7 & $4.60 \pm 0.01^{\mathrm{a}}$ & $146.67 \pm 2.22^{\mathrm{d}}$ & $387.68 \pm 7.32^{\mathrm{a}}$ & $6330.83 \pm 8.33^{b}$ & $1128.18 \pm 25.43^{\mathrm{e}}$ & $3865.28 \pm 3.18^{h}$ \\
\hline & 3 & $4.51 \pm 0.02^{b}$ & $182.22 \pm 2.22^{b}$ & $363.67 \pm 7.62^{b}$ & $5608.61 \pm 17.35^{c}$ & $1340.28 \pm 34.66^{\mathrm{C}}$ & $4670.83 \pm 10.42^{c}$ \\
\hline \multirow[t]{2}{*}{5} & 5 & $4.51 \pm 0.02^{b}$ & $147.41 \pm 4.63^{\mathrm{d}}$ & $369.23 \pm 5.54^{\mathrm{ab}}$ & $5561.39 \pm 17.35^{\mathrm{d}}$ & $1128.18 \pm 25.43^{\mathrm{e}}$ & $4073.61 \pm 3.18^{g}$ \\
\hline & 7 & $4.51 \pm 0.02^{b}$ & $98.52 \pm 3.39 \mathrm{~g}$ & $367.64 \pm 6.44^{\mathrm{b}}$ & $5555.83 \pm 14.43^{\mathrm{d}}$ & $961.53 \pm 25.43^{f}$ & $3538.89 \pm 4.34^{1}$ \\
\hline
\end{tabular}

Note: Different lowercase letters in the same column indicate that the values are significantly different $(\alpha=0.05)$. 
It is undoubted that the inoculum size determines the final spore number and the content of various nutrients. Restricted to the space of a triangular flask, a large inoculation was not beneficial for fermentation [38]. Thus, the inoculum size should be investigated. As shown in Figure $4 \mathrm{~A}$, the spore number of E. cristatum was proportional to the inoculum size ranging from $2.38 \times 10^{6}$ to $7.14 \times 10^{6} \mathrm{CFU}$. Nonetheless, the spore number decreased with the continued increase of the inoculum size. The flavonoids content was highest when the inoculum size was $7.14 \times 10^{6} \mathrm{CFU}$ (Figure 4B). The overall variation trend of flavonoids content was consistent with that of spore number. It suggested that the content of flavonoids in the fermentation mixture was codetermined by G. biloba leaves and Eurotium cristatum. TTLs content and PAC had no obvious changes. The activities of six enzymes were at the maximum when the inoculum size was $7.14 \times 10^{6} \mathrm{CFU}$ (Table 5). The spore number directly influenced the enzyme activity because these enzymes are secreted by Eurotium cristatum. Considering all the above changes, the optimal inoculum size was determined to be $7.14 \times 10^{6} \mathrm{CFU}$.
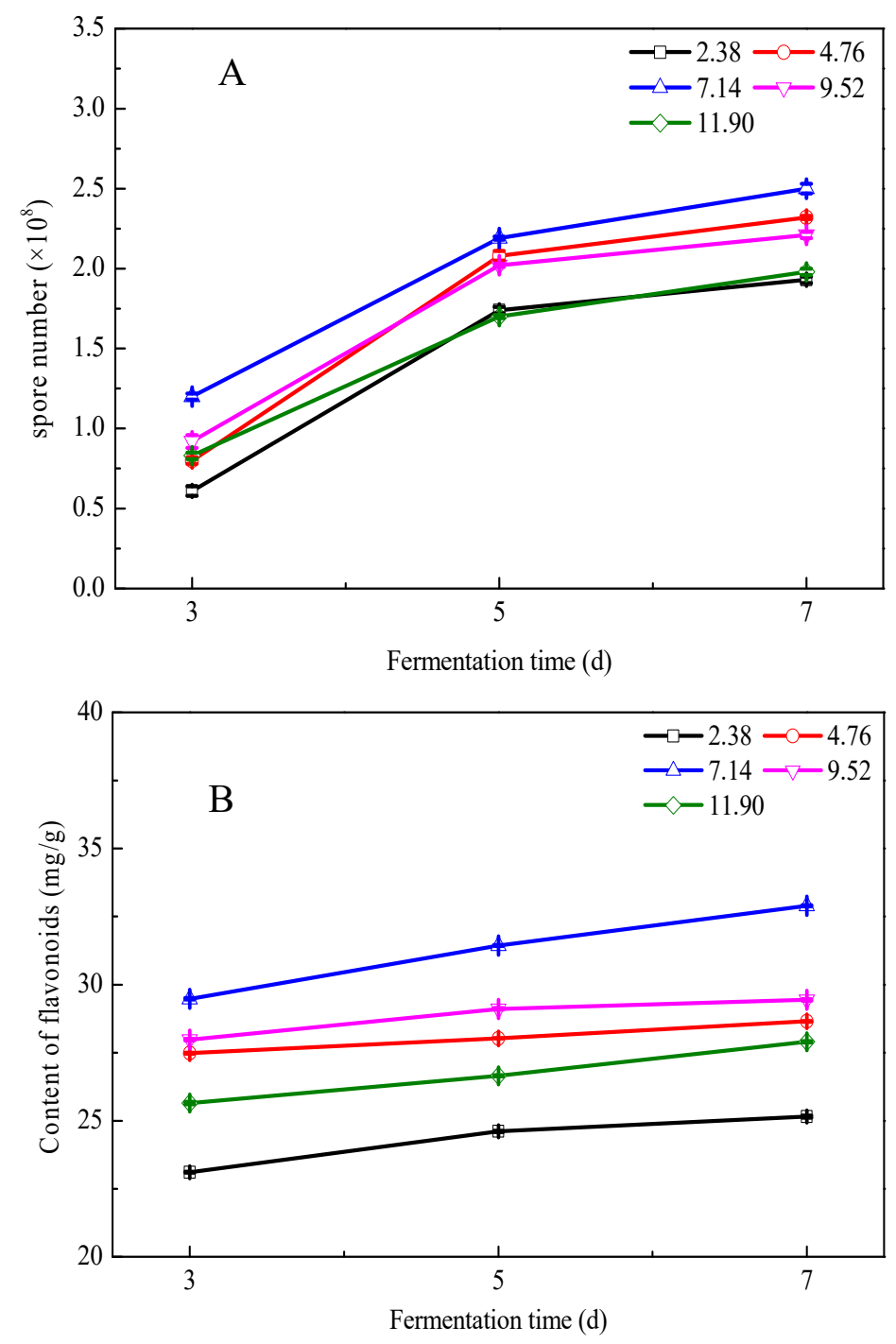

Figure 4. Effects of inoculum size $\left(\times 10^{6} \mathrm{CFU}\right)$ on different indexes: (A) spore number, and (B) flavonoid content. 
Table 5. Effects of inoculum size on the activities of several enzymes in fermented G. biloba leaves.

\begin{tabular}{|c|c|c|c|c|c|c|c|}
\hline \multirow{2}{*}{$\begin{array}{c}\text { Inoculum Size } \\
\left(\times 10^{6} \mathrm{CFU}\right)\end{array}$} & \multirow{2}{*}{ Time (d) } & \multicolumn{6}{|c|}{ Enzymes Activity (U/g) } \\
\hline & & Amylase & Lipase & Protease & Pectinase & Cellulase & Hemicellulase \\
\hline \multirow{4}{*}{2.38} & 3 & $4.55 \pm 0.02^{\mathrm{cd}}$ & $151.11 \pm 2.22^{\mathrm{d}}$ & $321.01 \pm 6.52^{g}$ & $4819.72 \pm 20.97^{g}$ & $1148.38 \pm 16.65^{g}$ & $4302.78 \pm 4.34^{\mathrm{h}}$ \\
\hline & 5 & $4.56 \pm 0.01^{\mathrm{cd}}$ & $115.56 \pm 2.22^{f}$ & $318.43 \pm 5.85^{g}$ & $4730.83 \pm 16.67^{\mathrm{h}}$ & $966.58 \pm 16.65^{j}$ & $4031.94 \pm 3.18^{\mathrm{i}}$ \\
\hline & 7 & $4.53 \pm 0.02^{\mathrm{d}}$ & $101.48 \pm 3.39 \mathrm{~g}$ & $304.35 \pm 7.32^{h}$ & $4655.83 \pm 16.67^{\mathrm{i}}$ & $744.38 \pm 34.66^{\mathrm{k}}$ & $3413.89 \pm 3.18^{\mathrm{m}}$ \\
\hline & 3 & $4.61 \pm 0.02^{\mathrm{ab}}$ & $195.56 \pm 2.22^{b}$ & $378.55 \pm 6.73^{c}$ & $6080.83 \pm 30.05^{\mathrm{b}}$ & $1400.88 \pm 25.43^{c}$ & $5059.72 \pm 3.18^{\mathrm{c}}$ \\
\hline \multirow[t]{3}{*}{4.76} & 5 & $4.60 \pm 0.01^{\mathrm{b}}$ & $149.63 \pm 3.39^{\text {de }}$ & $373.59 \pm 6.85^{\mathrm{cd}}$ & $6094.72 \pm 12.73^{\mathrm{b}}$ & $1299.88 \pm 16.65^{\mathrm{d}}$ & $4344.44 \pm 8.42^{\mathrm{g}}$ \\
\hline & 7 & $4.60 \pm 0.01^{b}$ & $100.00 \pm 2.22^{\mathrm{g}}$ & $362.88 \pm 7.88^{\mathrm{de}}$ & $6041.94 \pm 17.35^{\mathrm{b}}$ & $1072.63 \pm 16.65^{g}$ & $3747.22 \pm 3.18^{\mathrm{k}}$ \\
\hline & 3 & $4.66 \pm 0.03^{\mathrm{a}}$ & $223.70 \pm 3.39^{\mathrm{a}}$ & $395.62 \pm 5.63^{\mathrm{a}}$ & $6305.83 \pm 30.05^{\mathrm{a}}$ & $1587.73 \pm 76.30^{\mathrm{a}}$ & $5434.72 \pm 4.34^{\mathrm{a}}$ \\
\hline \multirow[t]{3}{*}{7.14} & 5 & $4.66 \pm 0.01^{\mathrm{a}}$ & $191.85 \pm 3.39^{b c}$ & $351.57 \pm 39.33^{\mathrm{e}}$ & $6316.94 \pm 17.35^{\mathrm{a}}$ & $1304.93 \pm 25.43^{\mathrm{d}}$ & $4552.78 \pm 3.18^{\mathrm{e}}$ \\
\hline & 7 & $4.65 \pm 0.02^{\mathrm{a}}$ & $154.07 \pm 3.39^{d}$ & $383.31 \pm 6.85^{\mathrm{b}}$ & $6316.94 \pm 19.25^{\mathrm{a}}$ & $1118.08 \pm 33.30 \mathrm{~g}$ & $3809.72 \pm 3.18^{j}$ \\
\hline & 3 & $4.58 \pm 0.01^{\mathrm{bc}}$ & $199.26 \pm 4.63^{b}$ & $355.54 \pm 6.52^{\mathrm{e}}$ & $5233.50 \pm 16.67^{\mathrm{d}}$ & $1451.38 \pm 16.65^{\mathrm{b}}$ & $5143.06 \pm 3.18^{\mathrm{b}}$ \\
\hline \multirow[t]{2}{*}{9.52} & 5 & $4.58 \pm 0.01^{\mathrm{bc}}$ & $183.70 \pm 3.39^{c}$ & $343.63 \pm 9.23^{f}$ & $5333.61 \pm 25.46^{\mathrm{c}}$ & $1264.53 \pm 25.43^{\mathrm{ef}}$ & $4504.17 \pm 2.08^{f}$ \\
\hline & 7 & $4.58 \pm 0.02^{\mathrm{bc}}$ & $135.56 \pm 4.44^{\mathrm{e}}$ & $336.09 \pm 6.18^{f}$ & $5297.50 \pm 41.67^{\mathrm{C}}$ & $991.83 \pm 25.43^{j}$ & $3650.00 \pm 5.51^{1}$ \\
\hline \multirow{3}{*}{11.90} & 3 & $4.51 \pm 0.01^{\mathrm{e}}$ & $188.15 \pm 3.39^{c}$ & $312.48 \pm 7.62^{g}$ & $4925.28 \pm 33.68^{\mathrm{e}}$ & $1229.18 \pm 50.87^{f}$ & $4608.33 \pm 2.08^{\mathrm{d}}$ \\
\hline & 5 & $4.52 \pm 0.01^{\mathrm{e}}$ & $143.70 \pm 3.39^{\mathrm{e}}$ & $302.56 \pm 6.52^{h}$ & $4861.39 \pm 17.35^{\mathrm{f}}$ & $1052.43 \pm 41.90^{\mathrm{h}}$ & $4025.00 \pm 4.17^{\mathrm{i}}$ \\
\hline & 7 & $4.51 \pm 0.02^{\mathrm{e}}$ & $100.74 \pm 3.39 \mathrm{~g}$ & $297.20 \pm 6.52^{h}$ & $4700.28 \pm 4.81^{\mathrm{h}}$ & $774.68 \pm 50.87^{k}$ & $3663.89 \pm 4.34^{1}$ \\
\hline
\end{tabular}

Note: Different lowercase letters in the same column indicate that the values are significantly different $(\alpha=0.05)$. 
In solid-state fermentation medium, the impacts of water content are important and various. The depletion of water affects the diffusion of gases, solutes, and osmosis caused by excessive metabolites in the vicinity of cells [39]. Too high or too low moisture degree both have negative effects on the growth of E. cristatum. Higher moisture degree will lead to the decrement of porosity and the increment of stickiness, and hinder the transformation of oxygen [40]. Lower moisture degree will lead to the decrease of water-soluble substances that can be utilized by E. cristatum [40]. As shown in Figure 5A,B, the optimal water content was $45 \% / 100 \mathrm{~g}$ wet medium in view of spore number and the content of flavonoids. The optimal water content was evidently lower than the previous report by Wang et al. using $A$. niger as the fermentation strain with optimal water content of $60 \%$ [36]. Table 6 shows that the activities of six enzymes were improved in the water content ranging from $35 \%$ to $45 \%(w / w)$, whereas the activity of the enzymes declined with further increasing water content. The cause of this phenomenon might be that the enzymes' activities are associated with the breathing pattern of strains. If the oxygen is sufficient, E. cristatum tends to adapt aerobic respiration, thus increasing enzyme activity. In summary, $45 \%(w / w)$ water content was adequate for the growth of E. cristatum.
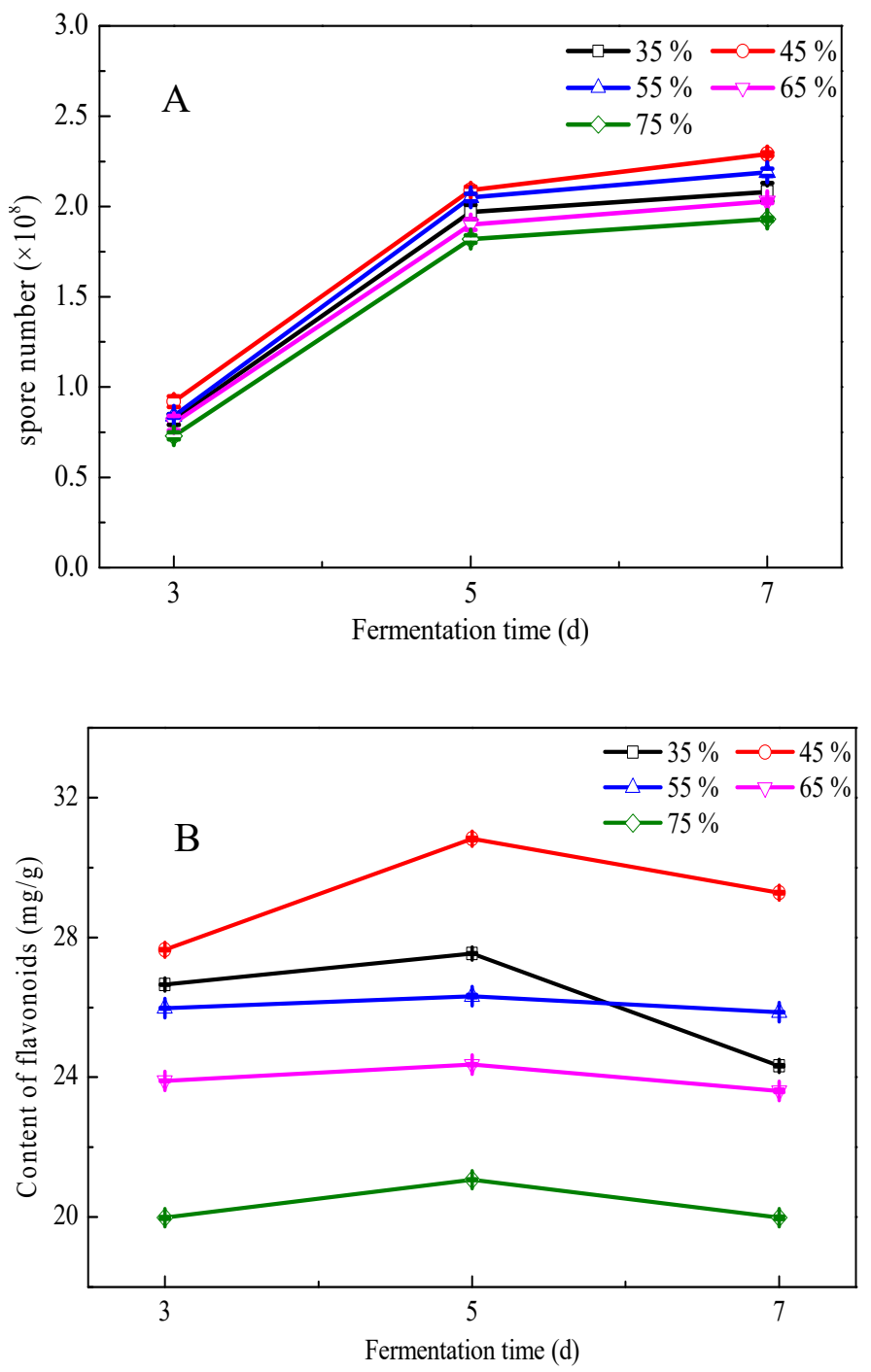

Figure 5. Effects of water content $(\%, w / w)$ on different indexes: (A) spore number and (B) flavonoid content. 
Table 6. Effects of the water content on the activities of several enzymes in fermented G. biloba leaves.

\begin{tabular}{|c|c|c|c|c|c|c|c|}
\hline \multirow{2}{*}{ Water Content $(\%, w / w)$} & \multirow{2}{*}{ Time (d) } & \multicolumn{6}{|c|}{ Enzymes Activity (U/g) } \\
\hline & & Amylase & Lipase & Protease & Pectinase & Cellulase & Hemicellulase \\
\hline \multirow{3}{*}{35} & 3 & $4.51 \pm 0.02^{\mathrm{c}}$ & $173.18 \pm 2.22^{b}$ & $375.43 \pm 6.13^{\mathrm{a}}$ & $5804.44 \pm 17.35^{\mathrm{c}}$ & $1273.27 \pm 9.61^{b}$ & $4486.47 \pm 2.08^{c}$ \\
\hline & 5 & $4.51 \pm 0.02^{\mathrm{c}}$ & $145.23 \pm 2.22^{\mathrm{d}}$ & $373.88 \pm 5.85^{\mathrm{a}}$ & $5712.28 \pm 8.33^{\mathrm{d}}$ & $877.88 \pm 16.65^{\mathrm{e}}$ & $3989.29 \pm 3.18^{h}$ \\
\hline & 7 & $4.52 \pm 0.01^{\mathrm{c}}$ & $92.77 \pm 3.39 \mathrm{~g}$ & $372.19 \pm 5.85^{\mathrm{a}}$ & $5688.93 \pm 12.73^{e}$ & $812.65 \pm 16.65^{f}$ & $3398.34 \pm 3.18^{k}$ \\
\hline \multirow{3}{*}{45} & 3 & $4.60 \pm 0.02^{\mathrm{a}}$ & $194.07 \pm 3.39^{\mathrm{a}}$ & $378.55 \pm 6.76^{\mathrm{a}}$ & $6111.39 \pm 20.97^{a}$ & $1431.18 \pm 9.61^{\mathrm{a}}$ & $4934.72 \pm 5.24^{\mathrm{a}}$ \\
\hline & 5 & $4.60 \pm 0.02^{\mathrm{a}}$ & $147.41 \pm 3.39^{d}$ & $378.15 \pm 8.25^{\mathrm{a}}$ & $6116.94 \pm 12.73^{\mathrm{a}}$ & $1289.78 \pm 25.43^{\mathrm{b}}$ & $4275.00 \pm 4.17^{\mathrm{e}}$ \\
\hline & 7 & $4.60 \pm 0.01^{\mathrm{a}}$ & $102.22 \pm 2.22^{f}$ & $374.98 \pm 6.44^{\mathrm{a}}$ & $6072.50 \pm 16.67^{b}$ & $1077.68 \pm 34.66^{\mathrm{c}}$ & $3691.67 \pm 4.17^{\mathrm{i}}$ \\
\hline \multirow{3}{*}{55} & 3 & $4.59 \pm 0.03^{\mathrm{ab}}$ & $176.30 \pm 3.39^{b}$ & $378.35 \pm 5.28^{\mathrm{a}}$ & $5808.61 \pm 120.57^{c}$ & $1284.73 \pm 16.65^{\mathrm{b}}$ & $4518.06 \pm 5.24^{b}$ \\
\hline & 5 & $4.57 \pm 0.02^{\mathrm{ab}}$ & $128.15 \pm 3.39^{\mathrm{e}}$ & $375.77 \pm 6.13^{\mathrm{a}}$ & $5730.83 \pm 22.05^{\mathrm{d}}$ & $900.93 \pm 25.43^{\mathrm{e}}$ & $4031.94 \pm 3.18^{f}$ \\
\hline & 7 & $4.57 \pm 0.01^{\mathrm{ab}}$ & $82.96 \pm 3.39^{h}$ & $373.59 \pm 5.85^{\mathrm{a}}$ & $5708.61 \pm 17.35^{\mathrm{d}}$ & $830.23 \pm 16.65^{\mathrm{f}}$ & $3608.33 \pm 2.08^{j}$ \\
\hline \multirow{3}{*}{65} & 3 & $4.51 \pm 0.01^{\mathrm{c}}$ & $162.96 \pm 3.39^{c}$ & $360.30 \pm 7.32^{b}$ & $5553.06 \pm 133.94^{\mathrm{f}}$ & $1269.58 \pm 16.65^{\mathrm{b}}$ & $4483.33 \pm 4.17^{c}$ \\
\hline & 5 & $4.52 \pm 0.05^{\mathrm{bc}}$ & $128.89 \pm 2.22^{\mathrm{e}}$ & $357.12 \pm 6.44^{b}$ & $5355.83 \pm 8.33^{h}$ & $1102.93 \pm 16.65^{c}$ & $3920.83 \pm 2.08 \mathrm{~g}$ \\
\hline & 7 & $4.52 \pm 0.02^{c}$ & $80.00 \pm 2.22^{h}$ & $341.05 \pm 5.85^{c}$ & $5403.06 \pm 12.73 \mathrm{~g}$ & $850.43 \pm 9.61^{\mathrm{f}}$ & $3406.94 \pm 4.34$ \\
\hline \multirow{3}{*}{75} & 3 & $4.50 \pm 0.02^{\mathrm{c}}$ & $142.96 \pm 3.39^{d}$ & $354.74 \pm 5.85^{b}$ & $4886.39 \pm 4.81^{\mathrm{j}}$ & $1077.68 \pm 50.87^{c}$ & $4330.56 \pm 6.36^{d}$ \\
\hline & 5 & $4.51 \pm 0.04^{\mathrm{c}}$ & $105.19 \pm 4.63^{f}$ & $341.65 \pm 5.85^{c}$ & $4847.50 \pm 44.10^{\mathrm{jk}}$ & $966.58 \pm 16.65^{\mathrm{d}}$ & $3615.28 \pm 4.34^{j}$ \\
\hline & 7 & $4.50 \pm 0.03^{c}$ & $74.07 \pm 3.39 j$ & $328.15 \pm 6.13^{d}$ & $4836.39 \pm 29.27^{\mathrm{k}}$ & $825.18 \pm 34.66^{f}$ & $2955.56 \pm 3.18^{1}$ \\
\hline
\end{tabular}

Note: Different lowercase letters in the same column indicate that the values are significantly different $(\alpha=0.05)$. 
After the above optimization, the fermentation time course was further investigated under the optimized conditions. Figure 6A shows that the spore number was enhanced with the extension of fermentation time until $192 \mathrm{~h}$, at which it began to drop for the following $24 \mathrm{~h}$. The main reason might be that the carbon and nitrogen sources in the medium had been depleted at $192 \mathrm{~h}$. The contents of TTLs and PAC had no remarkable changes as compared with the above-optimized data. The content of flavonoids increased until $120 \mathrm{~h}$ and then decreased. It is possible that flavonoids were consumed as energy for the growth of E. cristatum when nutrients were lacking in the medium [32]. As shown in Figure 6B, the protease, lipase, amylase, and pectinase activity maintained an upward trend until $120 \mathrm{~h}$, and then decreased. The cellulase and hemicellulase activity only increased within the first $48 \mathrm{~h}$, possibly because E. cristatum only secretes the two enzymes in the early stage of fermentation. Finally, the optimal $\mathrm{pH}$, inoculum size, water content, and fermentation time were decided to be 4.5, $7.14 \times 10^{6} \mathrm{CFU}, 45 \% / 100 \mathrm{~g}$, and eight days, respectively. Zhang et al. reported that G. biloba leaves fermented by Aspergillus niger could improve feed efficiency, intestinal morphology, digestion, and absorption of broilers as supplementation in the starter and grower diets [5]. In our work, G. biloba leaves fermented by E. cristatum possessed considerable improvement of flavonoids content. Further studies are necessary to investigate whether this improvement would have positive impacts on animals.
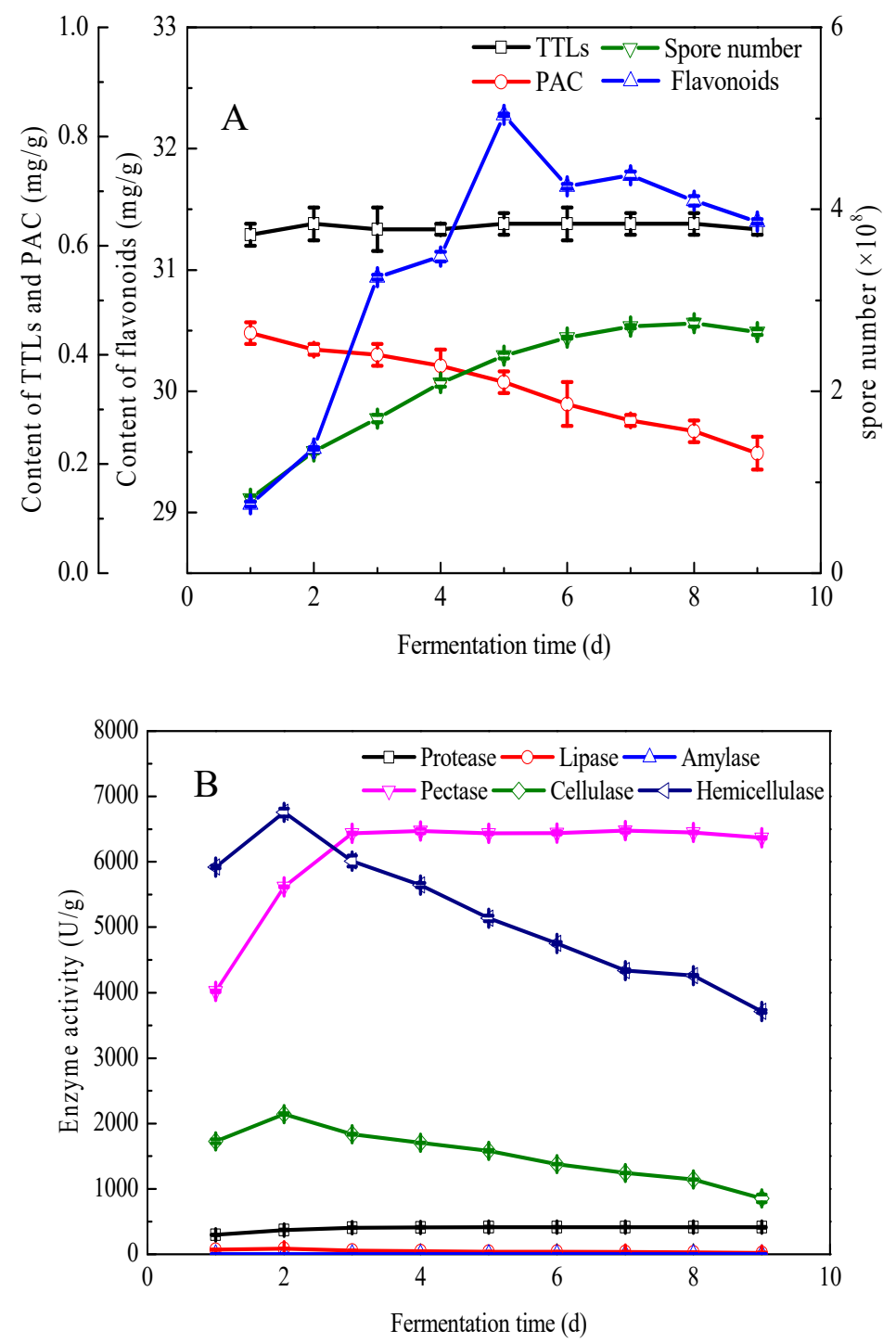

Figure 6. Effects of fermentation time (d) on different indexes: (A) spore number and (B) flavonoid content. 


\subsection{Component Analysis of the Fermented and Unfermented G. biloba Leaves}

Except for TTLs, PAC, and flavonoids, G. biloba leaves also contain proteins, free amino acids, PPAs, reducing sugars, ginkgolic acids, lignin, and aroma components. Ginkgolic acids are unwanted constituents in G. biloba leaves and are sought to be reduced by fermentation. The other ingredients were desired to be maintained or enhanced after fermentation. The results are listed in Table 7 . It was observed that the content of proteins was increased by $64.9 \%$, which was $14.82 \%$ higher than after fermentation with $A$. niger [27]. The content of free amino acids was decreased by $91.3 \%$. The changes demonstrated that the great mass of free amino acids was consumed by the E. cristatum and stored in the form of proteins [41]. For the feed, the value of proteins was reflected in not only the amount, but also the composition of various amino acids. The higher the percentage of essential amino acids account for, the higher nutritional value the protein has. The consumption of the semiessential amino acids can alleviate the wastage of essential amino acids [42]. The content of reducing sugars decreased by $47.1 \%$, which might be due to the fact that macromolecular carbohydrates added to the medium were not sufficient, resulting in the consumption of the soluble sugars in the fermentation process. When the fermentation was completed, the content of PPAs improved from the original 40.08 $\mathrm{mg} / \mathrm{g}$ to $44.34 \mathrm{mg} / \mathrm{g}$. As naturally occurring substances, PPAs have obvious curative effects on immune diseases such as hypertension, hyperlipidemia, and diabetes [43]. Surprisingly, the content of ginkgolic acids dropped to less than half of the initial amount. The components were also greatly reduced via solid-state fermentation of ginkgo leaf residues by Candida tropicalis and Aspergillus oryzae [16]. Ginkgolic acids are considered as a carcinogen and mutagen, which can cause skin, mucous membrane, and other allergic inflammatory responses [22]. Thus, the fermented G. biloba leaves would possess higher safety than the unfermented leaves. The content of lignin and cellulose also declined after the fermentation, owing to their degradation via the enzymes secreted by E. cristatum, which suggested that the fermented leaves possessed lesser nutrient resistance to animals than the unfermented leaves and confirmed fungal fermentation was available for ginkgo leaves. Fungal fermentation usually possess higher delignocellulose ability when a plant material rich in lignocellulose is used as the medium than bacterial fermentation due to the fungal extracellular enzymatic system and hyphal penetration power [44]. Table 8 shows that the antioxidant activity was improved in comparison with that before fermentation as a whole, even when four different extraction solvents were employed. For ABTS free radical scavenging capability, $80 \%(v / v)$ methanol was the best extraction solvent. For DPPH free radical scavenging capability, $80 \%(v / v)$ acetone was the best extraction solvent. The enhancement of antioxidant activity was valuable for the feed to prevent the nutrients from oxidizing. The aroma components also made a difference during the fermentation. Before fermentation, there were 30 kinds of aroma components detected in the G. biloba leaf powder, and most of them were alcohols and a small number of esters. After fermentation, there were also 30 kinds of aroma components, but the alcohols decreased, whereas the aldehydes and ketones increased. A. niger-fermented ginkgo leaves had more aroma components than the control and presented a pleasant fragrance, but the specific aroma components were not investigated [27]. The transformations of these aroma components may be concerned with auto-oxidation of E. cristatum, but the specific change mechanisms remain to be studied.

Table 7. The main components in the G. biloba leaves before and after fermentation.

\begin{tabular}{|c|c|c|c|c|c|c|c|}
\hline & Proteins (mg/g) & FAAs (ug/g) & RS * (ug/g) & PPAs (mg/g) & Gas * $(\%)$ & Cellulose (\%) & Lignin (\%) \\
\hline Before & $69.75 \pm 0.001^{b}$ & $2708.33 \pm 0.02^{\mathrm{a}}$ & $6214.29 \pm 0.01^{a}$ & $40.08 \pm 0.02^{b}$ & $2.33 \pm 0.01^{\mathrm{a}}$ & $60.92 \pm 0.00^{\mathrm{a}}$ & $1.82 \pm 0.03^{\mathrm{a}}$ \\
\hline After & $115.03 \pm 0.001^{\mathrm{a}}$ & $236.11 \pm 0.07^{\mathrm{b}}$ & $3285.71 \pm 0.01^{b}$ & $44.34 \pm 0.01^{\mathrm{a}}$ & $1.11 \pm 0.02^{\mathrm{b}}$ & $48.70 \pm 0.03^{\mathrm{b}}$ & $1.12 \pm 0.05^{\mathrm{b}}$ \\
\hline
\end{tabular}

* RS represents reducing sugars and GAs represent ginkgolic acids. Note: Different lowercase letters in the same column indicate that the values are significantly different $(\alpha=0.05)$. 
Table 8. The antioxidant activities of G. biloba leaves before and after fermentation.

\begin{tabular}{ccccc}
\hline Extraction Solvent & & $\begin{array}{c}\text { ABTS Free Radical } \\
\text { Scavenging Capability (\%) }\end{array}$ & $\begin{array}{c}\text { DPPH Free Radical } \\
\text { Scavenging Capability (\%) }\end{array}$ & $\begin{array}{c}\text { Total Reduction } \\
\text { Capacity }\end{array}$ \\
\hline \multirow{2}{*}{ Water } & Before & $1.540 \pm 0.002$ & $0.739 \pm 0.001$ & $0.282 \pm 0.004$ \\
& After & $2.269 \pm 0.001$ & $0.898 \pm 0.001$ & $0.360 \pm 0.002$ \\
$80 \%$ Methanol & Before & $3.943 \pm 0.001$ & $2.217 \pm 0.001$ & $0.263 \pm 0.004$ \\
& After & $4.592 \pm 0.001$ & $2.652 \pm 0.001$ & $0.332 \pm 0.001$ \\
$80 \%$ Ethanol & Before & $3.241 \pm 0.001$ & $2.304 \pm 0.001$ & $0.292 \pm 0.007$ \\
& After & $4.322 \pm 0.001$ & $2.579 \pm 0.001$ & $0.340 \pm 0.002$ \\
$80 \%$ Acetone & Before & $2.809 \pm 0.001$ & $2.449 \pm 0.001$ & $0.275 \pm 0.001$ \\
& After & $3.566 \pm 0.001$ & $2.782 \pm 0.001$ & $0.373 \pm 0.003$ \\
\hline
\end{tabular}

\section{Conclusions}

In this work, solid-state fermentation of G. biloba leaves using E. cristatum was fulfilled successfully. The spore number, main biologically active components, and several digestive enzymes' activities were chosen as the indexes to optimize the medium components and fermentation conditions. The optimal medium included $10 \%(w / w)$ whole G. biloba seeds in the medium. The optimal water content, $\mathrm{pH}$, inoculum size, and fermentation time for the growth of E. cristatum were found to be $45 \%, 4.5$, $4.76 \times 10^{7} \mathrm{CFU} / 100 \mathrm{~g}$ wet medium, and eight days, respectively. After fermentation, the spore number increased by about 40 times. The content of the TTLs remained stable. The content of flavonoids was enhanced up to $31.57 \pm 0.04 \mathrm{mg} / \mathrm{g}$, which was much higher than the original content of $14.44 \pm 0.06 \mathrm{mg} / \mathrm{g}$. The contents of protein and PPAs increased by $64.9 \%$ and $10.6 \%$, respectively. The antioxidant activity was also improved. The fermented leaves had more kinds of aroma substances than the unfermented leaves. The ginkgolic acids, lignin, and cellulose decreased by $52.4 \%, 38.5 \%$, and $20.1 \%$ than before, respectively. The hydrolysis of crude fibers by the enzymes was salutary for boosting taste and promoting the digestion of feed in animals. Therefore, the solid-state fermentation of G. biloba leaves using E. cristatum is expected to be a neoteric approach for the production of fermented feed.

\section{Patents}

A Chinese patent named as "a method of solid-state fermentation of G. biloba leaves using $E$. cristatum and its application" (CN201710734672.9) has been published.

Author Contributions: J.W. and E.S. conceived and designed the experiments; M.Z., Y.H. and X.G. performed the experiments; M.Z. wrote the manuscript; J.W., E.S. and F.C. revised the manuscript; All authors read and approved the final manuscript.

Funding: This research was funded by “China Postdoctoral Science Foundation (2016M600417 and 2017T100373)”, the "333 Project of Jiangsu Province (BRA2017458)", the "Six Talent Peaks Project in Jiangsu Province (2015-JY-016)", the "Open Project of State Key Laboratory of Natural Medicines (SKLNMKF201802)" and the "Project of Innovative and Entrepreneurial Training Program for College Students in Jiangsu Province".

Conflicts of Interest: The authors declare no conflict of interest.

\section{References}

1. Tang, K.L.; Caffrey, N.P.; Nóbrega, D.B.; Cork, S.C.; Ronksley, P.E.; Barkema,H.W.; Polachek, A.J.; Ganshorn, H.; Sharma, N.; Kellner, J.D. Restricting the use of antibiotics in food-producing animals and its associations with antibiotic resistance in food-producing animals and human beings: A systematic review and meta-analysis. Lancet Planet. Health 2017, 1, 316-327. [CrossRef]

2. Maron, D.F.; Smith, T.J.; Nachman, K.E. Restrictions on antimicrobial use in food animal production: An international regulatory and economic survey. Glob. Health 2013, 9, 48. [CrossRef] [PubMed]

3. Chen, K.L.; Kho, W.L.; You, S.H.; Yeh, R.H.; Tang, S.W.; Hsieh, C.W. Effects of Bacillus subtilis var. natto and Saccharomyces cerevisiae mixed fermented feed on the enhanced growth performance of broilers. Poult. Sci. 2009, 88, 309-315. [CrossRef] [PubMed] 
4. $\quad$ van Winsen, R.L.; Urlings, B.A.; Lipman, L.J.; Snijders, J.M.; Keuzenkamp, D.; Verheijden, J.H.; van Knapen, F. Effect of fermented feed on the microbial population of the gastrointestinal tracts of pigs. Appl. Environ. Microb. 2001, 67, 3071-3076. [CrossRef] [PubMed]

5. Zhang, X.H.; Cao, F.L.; Sun, Z.Y.; Yu, W.W.; Zhao, L.G.; Wang, G.B.; Wang, T. Effect of feeding Aspergillus niger-fermented G. biloba-leaves on growth, small intestinal structure and function of broiler chicks. Livestock Sci. 2012, 147, 170-180. [CrossRef]

6. Santoso, U.; Tanaka, K.; Ohtani, S.; Sakaida, M. Effect of fermented product from Bacillus subtilis on feed conversion efficiency, lipid accumulation and ammonia production in broiler chicks. Asian Austral. J. Anim. 2001, 14, 333-337. [CrossRef]

7. Wang, C.; Shi, C.; Zhang, Y.; Song, D.; Lu, Z.; Wang, Y. Microbiota in fermented feed and swine gut. Appl. Microbiol. Biotechnol. 2018, 102, 2941-2948. [CrossRef]

8. Bleichner, G.; Blehaut, H.; Mentec, H.; Moyse, D. Saccharomyces boulardii prevents diarrhea in critically ill tube-fed patients. Intens. Care Med. 1997, 23, 517-523. [CrossRef]

9. Okano, K.; Fukui, S.; Kitao, R.; Usagawa, T. Effects of culture length of Pleurotus eryngii grown on sugarcane bagasse on in vitro digestibility and chemical composition. Anim. Feed Sci. Technol. 2007, 136, 240-247. [CrossRef]

10. Veerabhadrappa, M.B.; Shivakumar, S.B.; Devappa, S. Solid-state fermentation of Jatropha seed cake for optimization of lipase, protease and detoxification of anti-nutrients in Jatropha seed cake using Aspergillus versicolor CJS-98. J. Biosci. Bioeng. 2014, 117, 208-214. [CrossRef]

11. Du, F.Y.; Li, X.M.; Li, C.S.; Shang, Z.; Wang, B.G. Cristatumins A-D, new indole alkaloids from the marine-derived endophytic fungus E. cristatum EN-220. Bioorg. Med. Chem. Lett. 2012, 22, 4650-4653. [CrossRef] [PubMed]

12. Zou, X.; Li, Y.; Zhang, X.; Li, Q.; Liu, X.; Huang, Y.; Tang, T.; Zheng, S.; Wang, W.; Tang, J. A new prenylated indole diketopiperazine alkaloid from E. cristatum. Molecules 2014, 19, 17839-17847. [CrossRef] [PubMed]

13. Du, F.Y.; Li, X.; Li, X.M.; Zhu, L.W.; Wang, B.G. Indolediketopiperazine alkaloids from E. cristatum EN-220, an endophytic fungus isolated from the marine alga Sargassum thunbergii. Mar. Drugs 2017, 15, 24. [CrossRef]

14. van Beek, T.A.; Montoro, P. Chemical analysis and quality control of G. biloba leaves, extracts, and phytopharmaceuticals. J. Chromatogr. A 2009, 1216, 2002-2032. [CrossRef] [PubMed]

15. Singh, B.; Kaur, P.; Singh, R.; Ahuja, P. Biology and chemistry of G. biloba. Fitoterapia 2008, 79, 401-418. [CrossRef] [PubMed]

16. Zhou, H.; Wang, C.Z.; Ye, J.Z.; Chen, H.X.; Tao, R.; Zhang, Y.S. Solid-state fermentation of G. biloba L. residue for optimal production of cellulase, protease and the simultaneous detoxification of G. biloba L. residue using Candida tropicalis and Aspergillus oryzae. Eur. Food Res. Technol. 2015, 240, 379-388. [CrossRef]

17. Ndjoko, K.; Wolfender, J.L.; Hostettmann, K. Determination of trace amounts of ginkgolic acids in G. biloba L. leaf extracts and phytopharmaceuticals by liquid chromatography-electrospray mass spectrometry. $J$. Chromatogr. B 2000, 744, 249-255. [CrossRef]

18. Cao, F.L.; Zhang, X.H.; Yu, W.W.; Zhao, L.G.; Wang, T. Effect of feeding fermented G. biloba leaves on growth performance, meat quality, and lipid metabolism in broilers. Poult. Sci. 2012, 91, 1210-1221. [CrossRef]

19. Yang, X.Y.; Lin, Y.X.; Li, Y. Effect of G. biloba extract on growth performance, slaughter performance and immune index in broilers. J. Fujian Agric. For. Univ. 2008, 37, 295-298.

20. Su, E.Z.; Yang, M.; Cao, J.; Lu, C.; Wang, J.H.; Cao, F.L. Deep eutectic solvents as green media for efficient extraction of terpene trilactones from G. biloba leaves. J. Liq. Chromatogr. R. Technol. 2017, 40, 385-391. [CrossRef]

21. Cao, J.; Chen, L.Y.; Li, M.H.; Cao, F.L.; Zhao, L.G.; Su, E.Z. Two-phase systems developed with hydrophilic and hydrophobic deep eutectic solvents for simultaneously extracting various bioactive compounds with different polarities. Green Chem. 2018, 20, 1879-1886. [CrossRef]

22. Li, Q.; Sun, W.; Jiang, Y.; Cao, F.L.; Wang, G.B.; Zhao, L.G. Extraction and biodegradation of ginkgolic acids from G. biloba sarcotestae. Front. Agric. Sci. Eng. 2017, 4, 465-472. [CrossRef]

23. National Standard of the People's Republic of China. Determination of the Total Amount of Free Amino Acids in Tea (GB/T8314-2013); China Standard Press: Beijing, China, 2013; pp. 478-496.

24. Yan, Z.; Fan, R.; Yin, S.; Zhao, X.; Liu, J.; Li, L.; Zhang, W.; Ge, L. Protective effects of G. biloba leaf polysaccharide on nonalcoholic fatty liver disease and its mechanisms. Int. J. Biol. Macromol. 2015, 80, 573-580. [CrossRef] [PubMed] 
25. Zhou, Z.L.; Li, F.; Li, J.W. Study on Relationship between Sugar Content and Cold-Hot Nature of 20 Kinds of Herbs by Fisher Analysis. World Sci. Technol. 2010, 12, 558-561.

26. Zhao, C.L. Use Sugarcane LEAVES to Produce Protein Feed by Fermentation. Master's Thesis, Guangxi University, Guiling, China, 2013.

27. Wang, J.H.; Cao, F.L.; Zhu, Z.L.; Zhang, X.H.; Sheng, Q.Q.; Qin, W.S. Improvement of Quality and Digestibility of Moringa Oleifera Leaves Feed via Solid-State Fermentation by Aspergillus Niger. Int. J. Chem. React. Eng. 2018, 16. [CrossRef]

28. Cao, J.; Chen, L.Y.; Li, M.H.; Cao, F.L.; Zhao, L.G.; Su, E.Z. Efficient extraction of proanthocyanidin from G. biloba leaves employing rationally designed deep eutectic solvent-water mixture and evaluation of the antioxidant activity. J. Pharm. Biomed. Anal. 2018, 158, 317-326. [CrossRef] [PubMed]

29. National Standard of the People's Republic of China. Determination of Enzymes Activity of Food Industry (GB 1886.174-2016); China Standard Press: Beijing, China, 2016.

30. Qa'dan, F.; Nahrstedt, A.; Schmidt, M.; Mansoor, K. Polyphenols from G. biloba. Sci. Pharm. 2010, 78, 897-908. [CrossRef]

31. Shahidi, F.; Naczk, M. Phenolics in Food and Nutraceuticals; CRC Press: Boca Raton, FL, USA, 2000; pp. $443-461$.

32. Liu, S.X.; Liu, S.C.; Li, Z.G. Effect of E. cristatum on flavones content in oat. China Brew. 2019, 38, 93-97.

33. Han, J.; Yan, Y.C.; Chang, H.Y.; Wang, H.; Yu, L.T. Isolation and purification of terpene lactones from G. biloba. Chin. Herbal. Med. 2002, 33, 99-102.

34. Wang, J.H.; Cao, F.L.; Su, E.Z.; Wu, C.E.; Zhao, L.G.; Ying, R.F. Improving flavonoid extraction from G. biloba leaves by prefermentation processing. J. Agric. Food Chem. 2013, 61, 5783-5791. [CrossRef]

35. Zhao, L.G.; Zhang, X.H.; Cao, F.L.; Sun, D.F.; Wang, T.; Wang, G.B. Effect of dietary supplementation with fermented Ginkgo-leaves on performance, egg quality, lipid metabolism and egg-yolk fatty acids composition in laying hens. Lives Sci. 2013, 155, 77-85. [CrossRef]

36. Moon, S.H.; Parulekar, S.J. A parametric study ot protease production in batch and fed-batch cultures of Bacillus firmus. Biotechnol. Bioeng. 1991, 37, 467-483. [CrossRef] [PubMed]

37. Liu, Z.Y.; Qin, J. Study on growth conditions of golden fungus of Fu tea. Guizhou Sci. 1991, 1, $20-24$.

38. Yalemtesfa, B.; Alemu, T.; Santhanam, A. Solid substrate fermentation and conversion of orange waste in to fungal biomass using Aspergillus niger KA-06 and Chaetomium Spp KC-06. Afr. J. Microbiol. Res. 2010, 4, 1275-1281.

39. De Loecker, R.; Goossens, W.; Van Duppen, V.; Verwilghen, R.; De Loecker, W. Osmotic effects of dilution on erythrocytes after freezing and thawing in glycerol-containing buffer. Cryobiology 1993, 30, 279-285. [CrossRef] [PubMed]

40. Anto, H.; Trivedi, U.; Patel, K. Glucoamylase production by solid-state fermentation using rice flake manufacturing waste products as substrate. Bioresour. Technol. 2006, 97, 1161-1166. [CrossRef]

41. Zhao, L.G.; Cao, F.L.; Yu, T.; Li, T.J.; Wang, G.B. Conditions of Solid Fermentation of G. biloba L. Leaves to Produce Forage Multienzyme and Analysis of the Product. Chem. Ind. For. Prod. 2007, 2, 76-80.

42. Zhao, G.H.; Chen, Z.D.; Wang, G.C.; Kan, J.Q. Effects of Modification on Functionalities and Structure of Corn Gluten Protein (II) Acylation. J. Chin. Cereal Oils Assoc. 2001, 3, 42-44.

43. Wang, C.Z.; Shen, Z.B.; Tan, W.H.; Yu, Q.; Daugavietis, M. The studies on the chemistry, purification and pharmacology of polyprenols from G. biloba L. Nat. Prod. Res. Dev. 2001, 2, 43-45.

44. Sharma, R.K.; Arora, D.S. Fungal degradation of lignocellulosic residues: An aspect of improved nutritive quality. Crit. Rev. Microbiol. 2015, 41, 52-60. [CrossRef]

(C) 2019 by the authors. Licensee MDPI, Basel, Switzerland. This article is an open access article distributed under the terms and conditions of the Creative Commons Attribution (CC BY) license (http://creativecommons.org/licenses/by/4.0/). 